\title{
Short-Term and Interannual Variability in Primary Production in the Low-Salinity Zone of the San Francisco Estuary
}

\author{
Wim J. Kimmerer • Alexander E. Parker • \\ Ulrika E. Lidström • Edward J. Carpenter
}

Received: 1 July 2011 /Revised: 19 January 2012 / Accepted: 27 January 2012 / Published online: 1 March 2012

(C) The Author(s) 2012. This article is published with open access at Springerlink.com

\begin{abstract}
We measured primary production during springsummer 2006-2007 to determine the carbon supply to the low-salinity pelagic food web of the San Francisco Estuary (SFE). Weekly or biweekly samples were taken at three stations of fixed salinity for size-fractionated primary production and biomass, both as chlorophyll and from biovolume based on counts. Error variance in productivity estimates arose mainly from the depth integration of ${ }^{14} \mathrm{C}$ uptake, showing the importance of productivity measurements at high light levels for estimates of depth-integrated production. Temporal and spatial variability in production were surprisingly small. Combining data from this study with long-term monitoring data, productivity and biomass were variable in time and salinity but without persistent patterns and with infrequent blooms. Production within the lowsalinity zone was unresponsive to variation in freshwater flow, in contrast to findings in other estuaries where nutrient loading drives variability in production and other regions of the SFE where production responds to residence time or to stratification. Estimated annual primary production was only 25 and $31 \mathrm{gC} \mathrm{m}^{-2}$ year $^{-1}$ during 2006 and 2007, only half of it in cells $>5 \mu \mathrm{m}$. These results imply that phytoplankton provided poor food web support for higher trophic levels, probably contributing to the long-term decline in fish abundance in the brackish to freshwater region of the estuary.
\end{abstract}

Keywords Primary production · Phytoplankton - Biomass . Chlorophyll · Temporal variability · San Francisco Estuary

W. J. Kimmerer $(\bowtie) \cdot$ A. E. Parker · U. E. Lidström •

E. J. Carpenter

Romberg Tiburon Center,

3152 Paradise Drive,

Tiburon, CA 94920, USA

e-mail: kimmerer@sfsu.edu

\section{Introduction}

Phytoplankton primary production is a key driver of the productivity and dynamics of estuarine food webs. Crosssystem comparisons (Nixon 1988) illustrate the link between productivity of phytoplankton and productivity at higher trophic levels. Phytoplankton production remains the dominant driver of pelagic food webs in many estuaries (Sobczak et al. 2005), although marshes contribute substantial organic carbon to pelagic food webs in some estuaries (e.g., Dame et al. 1986; Kneib 1997; Jassby et al. 2002).

Despite its importance, primary production is usually inferred from related variables, notably chlorophyll concentration and various optical measurements (e.g., Harding et al. 2002), rather than by direct measurement. For example, primary production where light is limiting has been estimated from relationships with chlorophyll concentration, incident photosynthetically active radiation (PAR), and extinction coefficient (Cole and Cloern 1984; Jassby et al. 2002). These relationships are useful for estimating primary production only if the underlying physiological parameters of the phytoplankton do not change.

The variables controlling phytoplankton production can have strong seasonal and interannual signals. Seasonal and longer-term patterns of chlorophyll concentration vary widely among estuaries (Cloern and Jassby 2008, 2010). PAR is both seasonally variable and weather dependent. Extinction coefficient can vary because of light absorption either by suspended sediments or by the phytoplankton cells themselves. The underlying physiology of the phytoplankton may also vary substantially on time scales relevant to estimating primary production from models (Parker et al. 2012).

Variability in the controls on primary production implies variability in production itself, which must be separated from measurement error. Few studies have addressed the 
uncertainty in measurements of primary production or used that uncertainty in calibrating models such as that of Cole and Cloern (1984). Although the error inherent in individual ${ }^{14} \mathrm{C}$ measurements is small (e.g., $10 \%$, Steemann Nielsen 1952), calculating in situ productivity and integrating it through the water column introduce several additional sources of error that widen confidence intervals around the calculated values. In addition to error in measuring ${ }^{14} \mathrm{C}$ uptake, there are errors in estimating time-integrated PAR and extinction coefficient (for the more common simulated in situ incubations) and in the mathematical models used to integrate data from individual measurements of ${ }^{14} \mathrm{C}$ uptake at a limited number of light levels.

Studies of primary production do not always provide insights into the contributions of different size fractions to total production (but see, e.g., Malone 1977; Cole et al. 1986; Iriarte and Purdie 1994; Smith and Kemp 2001). Only the production in cells larger than $\sim 5 \mu \mathrm{m}$ is available to grazers such as copepods (e.g., Berggreen et al. 1988). Partitioning production at least into size classes allows for food web models that account for variation in trophic linkages and efficiency.

In this paper, we present the results of primary productivity measurements made in the low-salinity zone (LSZ) of the San Francisco Estuary during spring and summer of 2006 and 2007. The objectives of this study were to investigate short-term (weeks) variability in productivity within a narrow salinity range and the variability of productivity between spring and summer, between years, between autotrophic size classes, and with freshwater flow. Ancillary information on taxonomic composition and biomass determined from biovolume helped in interpreting the productivity data, and data from a long-term monitoring program provided a longer-term context and a means to estimate annual production. A companion paper interprets these data in the context of phytoplankton physiology and the predictability of primary productivity from biomass and light (Parker et al. 2012).

This work is part of a study of the pelagic food web of this region of the estuary, motivated in part by concern over declines in several pelagic fish species around 2002 (Pelagic Organism Decline, Sommer et al. 2007). Statistical modeling showed that fish abundance responded to several covariates including freshwater flow but that these covariates could not explain the decline (Thomson et al. 2010). Potential causes of the decline include changes in the pelagic food web (Baxter et al. 2008), particularly in the LSZ which is the summer-fall habitat of the endangered delta smelt Hypomesus transpacificus (Sommer et al. 2007; Brown et al. 2008). Our study focused on springsummer to capture any spring blooms and to provide detailed data on the dry period that is the focus of current management efforts (Baxter et al. 2008).

\section{Methods}

Study Site The San Francisco Estuary (SFE; Fig. 1) has a Mediterranean climate with the highest freshwater runoff in winter-spring and very little precipitation between June and October. The northern estuary is divided into a series of shallow basins, each with one or two deep channels running through it. The Sacramento-San Joaquin Delta forms the landward portion of the estuary. This region consists of a network of channels and sloughs, with river inputs from the east, especially from the Sacramento River, and large water diversion facilities in the south. Our study focuses on the low-salinity zone defined here as salinity $0.5-5$, typically located in Suisun Bay in spring and in the western Delta in summer-fall.

High turbidity in the SFE, due almost entirely to suspended inorganic sediment, limits primary productivity (Cole and Cloern 1984). Turbidity is affected by windand tide-driven vertical mixing and resuspension of sediment and is particularly high in shallow areas and during periods of strong wind such as most summer afternoons. High rates of grazing by the introduced clam Corbula amurensis have limited the buildup of phytoplankton biomass since the clam spread throughout the northern estuary in 1987 (Alpine and Cloern 1992). The clams also ingest bacteria (Werner and Hollibaugh 1993) and microzooplankton (Kimmerer et al. 1994; Greene et al. 2011). Nutrient concentrations rarely limit phytoplankton growth rate, although high ammonium concentrations appear to constrain the maximum growth rates of at least some phytoplankton taxa (Wilkerson et al. 2006). Dugdale et al. (2007) reported that when light conditions were favorable, high nitrate combined with low ammonium have stimulated brief spring blooms.

Field Methods Samples were taken at target surface salinities of $0.5,2$, and 5 (these values are used as station identifiers) in spring-summer of 2006 and 2007. Hydrology during the spring differed greatly between the 2 years: 2006 was very wet and 2007 was dry (Fig. 2). As a result, in spring 2006, the LSZ was much farther seaward than usual and did not reach its usual late-summer position at the east end of Suisun Bay until mid-August (Fig. 1). This also meant that sampling during the spring of 2006 was in deeper channels of Central Bay and San Pablo Bay, where stratification was often strong, with a bottom salinity as much as 21 above that at the surface at station 2 (data not shown). Although samples were taken at the surface, this stratification introduces some uncertainty in the analysis of data from March to mid-May. When the LSZ was in the relatively shallow Suisun Bay and western Delta, there was little stratification, with a median vertical salinity range of 0.5 for all samples from mid-May through August 2006 and 
Fig. 1 Map of the San Francisco Estuary. Darker shading indicates the $10-\mathrm{m}$ depth contour. Limits of sampling in the low-salinity zone (salinity 0.5 to 5 ) are indicated by dashed (2006) and solid (2007) lines. The diamond represents the incubation site at the Romberg Tiburon Center

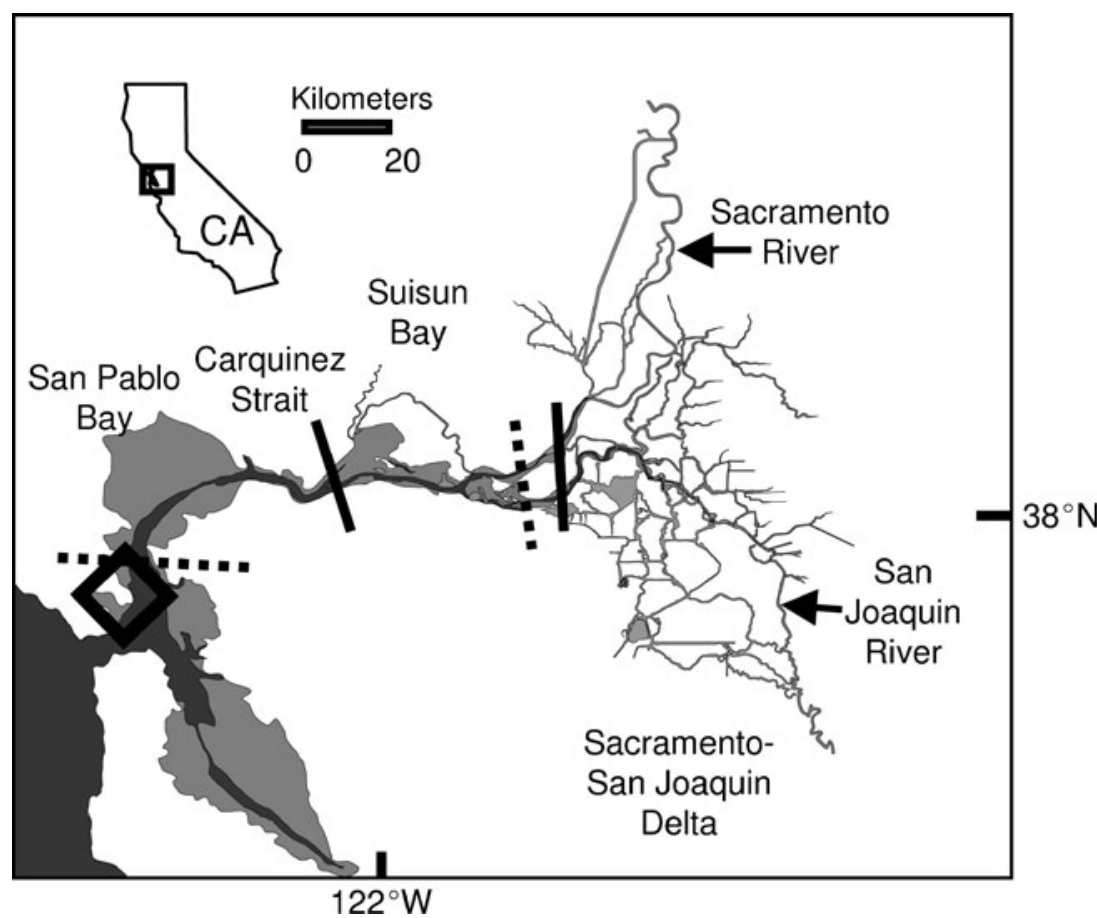

March-August 2007 (see also Kimmerer et al. 1998). At these times, the phytoplankton would have been subject to vigorous vertical mixing by strong tidal currents.

Samples were taken weekly in 2006 and biweekly to weekly in 2007 from March through August from the R/V Questuary. Secchi disk depth was recorded at each station along with temperature and salinity profiles using a Seabird SBE-19 CTD. PAR was measured with a LiCor Underwater

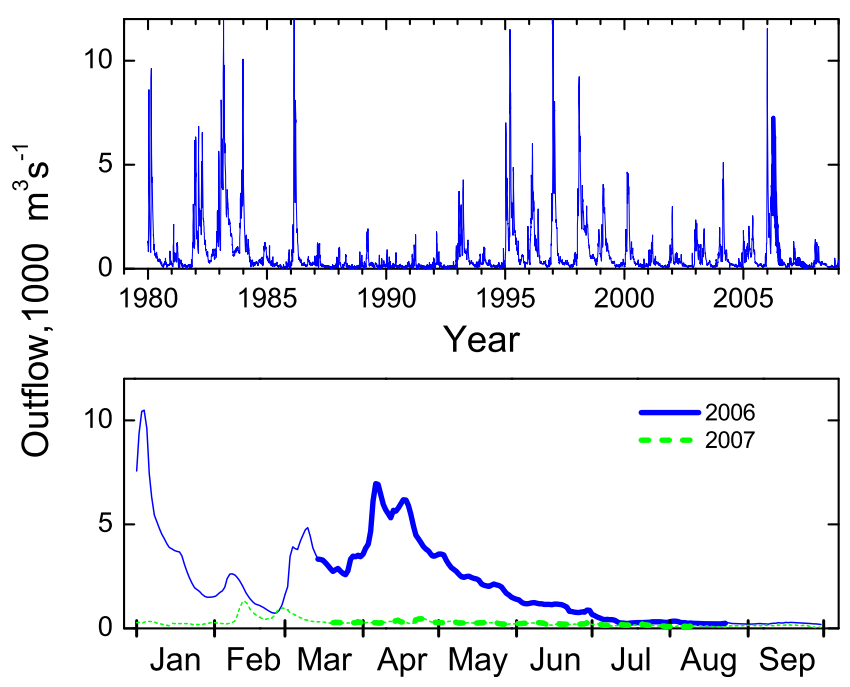

Fig. 2 Freshwater flow estimated at the western margin of the Sacramento-San Joaquin Delta (net delta outflow, http://www.water.ca.gov/ dayflow/output/). Upper graph shows daily outflow from 1980 through September 2009; lower graph shows flow during 2006 and 2007 with the field season indicated by thick lines
Spherical Quantum PAR sensor mounted on the CTD cage. In most cases, profiles were taken both upon arriving at the station and before departing. The median interval between pairs of profiles was $30 \mathrm{~min}$.

Surface water was collected in an acid-cleaned $(10 \%, v / v$ $\mathrm{HCl})$ plastic bucket and transferred to 20-1 polycarbonate carboys. Samples were stored in coolers in the dark and transported to the Romberg Tiburon Center where all samples were processed on the same day. A water sample was also placed in an airtight 20-ml glass scintillation vial, sealed with a Tefloncoated inverted-cone cap, and preserved on board with $200 \mu \mathrm{l}$ of $5 \% \mathrm{HgCl}_{2}$ for dissolved inorganic carbon (DIC) analysis to be used for estimating productivity.

Laboratory Methods Phytoplankton samples $(250 \mathrm{ml})$ from the 20-1 carboys were preserved with 5\% acid Lugol's solution and stored at room temperature in the dark. Subsamples $(15 \mathrm{ml})$ were concentrated by centrifuging for $30 \mathrm{~min}$ at 2,000 rpm (modified from Throndsen 1978), then viewed in a Sedgwick-Rafter counting chamber (Guillard 1978) under a Zeiss Axioskop D-7082 fluorescence microscope at $\times 320$ magnification. Cells were counted along one or more complete transects (17$20 \mathrm{~mm}$ ) to count at least 100 of the most common cell types. Cells were identified to species, genus, or higher taxonomic group using the taxonomic keys of Wehr and Sheath (2003) and Tomas (1996). Individual cells in chains were counted. The dimensions of the most common cell size for all cell types were recorded from each sample for biovolume calculations. 
Picoplankton samples $(100 \mathrm{ml})$ were held in a beaker for 30-60 min to allow sediment particles to settle out. A $10-\mathrm{ml}$ subsample was taken from the surface of the beaker using a syringe and preserved with $2 \%$ formaldehyde for $2 \mathrm{~min}$. The sample was then filtered onto a $0.6-\mu \mathrm{m}$ black polycarbonate filter (25 mm diameter, Osmotic Inc.) which was mounted onto a clean glass microscope slide using non-drying immersion oil (Type DF, Cargille Laboratories Inc.) and stored in the dark at $-20^{\circ} \mathrm{C}$ for no more than 6 months before examination (MacIsaac and Stockner 1993). Autofluorescing picoplankton cells were counted at $\times 1,000$ magnification $(\times 100$ oil immersion objective) using the Zeiss Axioskop microscope with a HBO 100 mercury lamp. Twenty fields were counted for each sample.

Biomass was calculated from biovolume, estimated by assigning each cell type a simple shape (sphere, cylinder, or prolate spheroid; Menden-Deuer and Lessard 2000). For the nano- and microplankton, the median value of the recorded dimensions for each cell type in each salinity value and year was used to calculate the cell volume (Hillebrand et al. 1999). The carbon content was calculated from biovolume using carbon density provided by Menden-Deuer and Lessard (2000; Table 4) for diatoms and for other protists excluding picoplankton, each separated into cells $\geq$ or $<3,000 \mu \mathrm{m}^{3}$. Picoplankton carbon was calculated as $0.25 \mathrm{pg} \mathrm{C}^{-1 l^{-1}}$ assuming a $1-\mu \mathrm{m}$-diameter sphere and carbon density from Verity et al. (1992). For the purposes of this paper (see Lidström 2009), biomass data were aggregated into: pennate diatoms $(>5 \mu \mathrm{m})$, centric diatoms $(>5$ and $<5 \mu \mathrm{m})$, cryptophytes $(>5$ and $<5 \mu \mathrm{m}$ ), microflagellates ( $>5$ and $<5 \mu \mathrm{m}$ ), chlorophytes ( $>5$ and $<5 \mu \mathrm{m}$ ), dinoflagellates $(>5 \mu \mathrm{m})$, and picoplankton.

Extracted chlorophyll $a$ was measured fluorometrically on two size fractions (Arar and Collins 1992). Triplicate water samples of $50-100 \mathrm{ml}$ were filtered onto $25-\mathrm{mm}$ $\mathrm{GF} / \mathrm{F}$ filters $(0.7 \mu \mathrm{m}$ nominal pore size, Whatman), and samples of $25-50 \mathrm{ml}$ were filtered onto 25 -mm-diameter, $5-\mu \mathrm{m}$ pore-size polycarbonate filters (GE Water and Process Technologies). Sample volumes were chosen to limit filtration times to $<10$ min under gentle vacuum $(<250 \mathrm{mmHg})$. Filters were stored in the dark at $-20^{\circ} \mathrm{C}$ in borosilicate glass tubes for up to 2 weeks, then chlorophyll was extracted in $8 \mathrm{ml}$ of $90 \%$ acetone for $24 \mathrm{~h}$ at $-20^{\circ} \mathrm{C}$ and read on a Turner Designs Model 10-AU fluorometer calibrated with chlorophyll $a$ (Sigma Chemical). Chlorophyll $a$ concentrations were calculated as in Holm-Hansen et al. (1965), correcting for pheophytin using $10 \% \mathrm{HCl}$.

Samples for DIC were stored in the dark at $4{ }^{\circ} \mathrm{C}$ for no more than 2 months before analysis. DIC was measured as the mean of three replicate sample injections using a Monterey Bay Aquarium Research Institute clone DIC analyzer (Friederich et al. 2002; Sharp et al. 2009) calibrated with a certified standard from the Scripps Institution of Oceanography (A. Dickson Laboratory). The coefficients of variation were always $<1.2 \%$. Water for nutrient analysis was filtered through a Whatman GF/F filter previously baked at $450^{\circ} \mathrm{C}$ for $4 \mathrm{~h}$. Separate aliquots were prepared for autoanalyzer nutrients [nitrate + nitrite $\left(\mathrm{NO}_{3}+\mathrm{NO}_{2}\right)$, phosphate $\left(\mathrm{PO}_{4}\right)$, and silicate $\left.\left(\mathrm{Si}(\mathrm{OH})_{4}\right)\right]$ and ammonium $\left(\mathrm{NH}_{4}\right)$. Autoanalyzer nutrient concentrations were determined using a Bran+Luebbe Technicon Autoanalyzer II (Bran + Leubbe 1999) except for $\mathrm{Si}(\mathrm{OH})_{4}$ which was determined as in Whitledge et al. (1981). $\mathrm{NH}_{4}$ was determined manually by the method of Solórzano (1969), using a Hewlett Packard diode array spectrophotometer using a 10-cm path-length cell.

Primary production was measured using the ${ }^{14} \mathrm{C}$ light-dark bottle method (JGOFS 1996). Samples were incubated in a flowing seawater bath on the seawall at the Romberg Tiburon Center (Fig. 1) with layers of window screen used to obtain ten light levels $(100 \%, 50 \%, 25 \%, 15 \%, 10 \%, 6 \%, 4 \%, 3 \%$, $1 \%$, and $0.1 \%$ of ambient light), along with two dark-bottle controls. In 2006, the incubations lasted $6 \mathrm{~h}$, typically from noon to 18:00 h, except on 14 March when the incubation lasted for $24 \mathrm{~h}$. In 2007, all incubations were for $24 \mathrm{~h}$ from noon. This gave values that should be close to net primary production at near-saturating light levels (Harding et al. 2002) but closer to gross production at low light levels. Hourly primary production estimates from 2006 were converted to $24 \mathrm{~h}$ rates by multiplying by day length. A comparison of other slight differences in methods between the 2 years $\left({ }^{14} \mathrm{C}\right.$ activity added, acid added, subsample sizes) showed little difference in estimated productivity (Lidström 2009).

At the beginning of each incubation, samples were taken for total ${ }^{14} \mathrm{C}$ activity from each $50 \%$ light incubation bottle; after incubation, total activity was sampled from all bottles. Then $50 \mathrm{ml}$ from each bottle was filtered onto a GF/F filter and $25 \mathrm{ml}$ onto a $5-\mu \mathrm{m}$ polycarbonate filter. Filters were placed in scintillation vials and fumed with $250 \mu \mathrm{l}$ of $5 \%$ or $10 \% \mathrm{HCl}$ overnight to remove any unincorporated ${ }^{14} \mathrm{C}$. HiSafe scintillation cocktail (Perkin Elmer) was added, and the vials were stored in the dark for $24 \mathrm{~h}$ before counting on a Perkin Elmer Winspectral Guardian LSC liquid scintillation counter. Counts were converted to the rate of carbon fixation according to JGOFS (1996).

Ancillary Data PAR data were obtained from a sensor at the Romberg Tiburon Center (RTC; http://sfbeams.sfsu.edu) near the incubation site. Daily total PAR was available for most of the sampling dates of 2006 and all of the dates in 2007. PAR data were not available from the sampling region, where cloud cover can be considerably less than at Tiburon. Data from pyranometers were obtained from the California Irrigation Management Information System (http://wwwcimis.water.ca.gov) for two monitoring sites in San Pablo Bay, 12 and $24 \mathrm{~km}$ north of RTC, and four sites near where samples were collected. Solar radiation flux density in watts $\mathrm{m}^{-2}$ averaged over $24 \mathrm{~h}$ was converted 
to PAR ( $\mu \mathrm{mol}$ photons $\mathrm{m}^{-2} \mathrm{~s}^{-1}$ ) under the assumption that photosynthetically active light comprises about $45 \%$ of the total quanta detected by a pyranometer, giving a conversion factor of $0.18 \mu \mathrm{mol}$ photons $\mathrm{s}^{-1} \mathrm{~W}^{-1}$ (Morel and Smith 1974).

Calculations Shipboard water-column PAR profiles were used to determine extinction coefficients $(k)$ for use in extrapolating simulated in situ productivity to the field. The model for $k$ is

$\ln (\mathrm{PAR})=a-k z$

where $z$ is depth and $a$ and $k$ are parameters fitted by linear regression. However, in the turbid water of the estuary $\ln$ (PAR) was linear over only a limited range of depth, constraining the number of data points available for the analysis. To determine objectively the range of linearity while maximizing the amount of data, we started with the uppermost 10 data points for which PAR $>0.1 \mu \mathrm{mol} \mathrm{m} \mathrm{m}^{-2}$ and $z<5 \mathrm{~m}$, and fit Eq. 1, then progressively added data points at the bottom of the profile, stopping when the error variance began to increase. Graphical analysis of all profiles revealed that this procedure always captured the log-linear region of the PAR profiles.

Instrument malfunctions and maintenance resulted in 22 missing samples out of 123 total. We developed a relationship between the extinction coefficient $k$ and the inverse of Secchi depth for all samples when both were available. Extinction coefficients from replicate profiles were averaged. Because the variance clearly increased with the mean, we used a generalized linear model with linear link function and variance proportional to the mean squared (McCullagh and Nelder 1989). The fit was better without an intercept, as determined by the lower value of the Akaike information criterion. The extinction coefficient was related to Secchi depth by

$k=(1.24 \pm 0.06) / \sec \operatorname{chi}(\mathrm{m})$

with the $95 \%$ confidence interval $(86 d f)$. The approximate coefficient of determination was 0.59 , and the standard deviation of the residuals was $0.93 \mathrm{~m}^{-1}$. Predictions from a previous relationship of extinction coefficient to the inverse of Secchi depth including the intercept $(0.4+1.09 /$ Secchi; Cloern 1991) agree with those from Eq. 2 within $10 \%$ over the range of values of Secchi depth from this program.

We fit the productivity vs. light data for each individual set of measurements to the three-parameter function of Macedo and Duarte (2006) using the measured productivity at each light level and the PAR data from the incubation site:

$\mathrm{PP}=\frac{\mathrm{PAR}}{a \mathrm{PAR}^{2}+b \mathrm{PAR}+c}$

where PAR is photosynthetically active radiation (mol $\left.\mathrm{m}^{-2} \mathrm{~d}^{-1}\right)$, PP is primary productivity $\left(\mathrm{mgC} \mathrm{m} \mathrm{m}^{-2} \mathrm{~d}^{-1}\right)$, and $a, b$, and $c$ are parameters. This function accommodates photoinhibition which was observed in most productivity profiles. A more commonly used model is the hyperbolic tangent (Jassby and Platt 1976) which does not accommodate photoinhibition. As a check on model selection, we fitted a hyperbolic tangent to data excluding points with PAR greater than the mean value at which photoinhibition was observed in our data, $27.6 \mathrm{~mol} \mathrm{~m}^{-2}$ day $^{-1}$. Integrated production determined as described below using these two alternatives were strongly correlated $(r=0.99)$, but the values determined using the tanh curve averaged 7\% lower than those using Eq. 3.

The incubation data used to fit Eq. 3 did not meet the criteria for least-squares regression, requiring alternative fitting methods. Variance of the productivity values clearly increased with the mean, and there were some evident outliers. We applied an iterative procedure for fitting the data and identifying no more than one outlier per profile. First the model was fitted with variance proportional to the measured values using the function gnls in Splus (Venables and Ripley 2003). The model was then re-fitted iteratively with the variance proportional to the predicted value, until the absolute difference of the residual variance between successive estimates was $<0.0001$. Provisional outliers were identified conservatively as follows. First, any value $>2$ standard errors away from the predicted value for the corresponding PAR value was considered a provisional outlier. Second, the curves were refit with each data point deleted one at a time (except the two points at the highest PAR which could not be clearly identified as outliers). A point was considered a provisional outlier if the residual standard error of the fit without that point was $<70 \%$ of the median for all fits with that point, that is, eliminating that point greatly improved the fit. Finally, if an outlier was provisionally identified by either of these two methods, the model was then refit without that point. If the offending point was $>2$ standard errors away from the newly predicted value, it was excluded from the final curve-fitting. A total of 82 profiles out of 217 had one value eliminated, mostly at low values of irradiance.

Although photoinhibition was usually observed in data from the incubations, it may be uncommon in the field because individual cells in a turbulent water column may be exposed to bright light for only limited periods (Macedo and Duarte 2006). The time constant for onset of photoinhibition is $\sim 1 \mathrm{~h}$ (Pahl-Wostl and Imboden 1990). By contrast, the overturning time scale in the shallow, usually unstratified waters where this work was done is $\ll 1 \mathrm{~h}$. From Fischer et al. (1979), the overturning timescale is

$\mathrm{T}=0.4 H^{2} / \varepsilon \approx 6 H / u^{*}$

where $H$ is water depth, $\varepsilon$ is the vertical eddy diffusivity, and $u^{*}$ the friction velocity. With a depth $H$ of $5 \mathrm{~m}$ and typical 
friction velocity $u^{*}$ of $0.05 \mathrm{~ms}^{-1}$ (Fischer et al. 1979), the overturning timescale would be around $10 \mathrm{~min}$. Since only the top $\sim 1 \mathrm{~m}$ of the water column is well-lit, the timescale for illumination of individual cells would be a few minutes, far shorter than the timescale for photoinhibition. Thus, we are justified in assuming that photoinhibition did not occur in the field.

To estimate productivity in the field, we used the fitted curves of productivity vs. PAR but replaced the portion due to photoinhibition with a constant equal to the maximum productivity. This extrapolation used the PAR estimates for Suisun Bay and the extinction coefficients determined for each station. Integrated production was determined by numerically integrating calculated productivity at $1-\mathrm{cm}$ intervals from 0 to $5 \mathrm{~m}$. Calculated productivity below $5 \mathrm{~m}$ never exceeded $0.4 \%$ of that above $5 \mathrm{~m}$.

We used a resampling method to determine confidence intervals for individual production estimates, incorporating error arising from estimates of incident PAR and extinction coefficient and from the fit of Eq. 3. For extinction and PAR, we sampled from normal distributions with means of 0 and their respective standard errors. For the fit of the productivity-PAR curve, we sampled the residual standard error and multiplied the result by the square root of the predicted value (since the original fit had variance proportional to the mean). This result is represented by the confidence limits in Fig. 3A, B. Integrated production was calculated as described above for each simulated profile $(N=1,000$ for each of the original 217 profiles), and $95 \%$ confidence limits were determined as percentiles of the simulated values (Fig. 3B, C). To examine the contributions of the three error terms to the overall error, we repeated the above simulation three times, each with only one of the three error terms included $(N=100$ each).

Long-term data on chlorophyll concentration and Secchi depth were obtained from a monitoring program in the upper estuary (Interagency Ecological Program, IEP; Sommer et al. 2007) for comparison with our data and to provide a longerterm context. We used data from the low-salinity zone, defined here as salinity of $0.5-10$ to expand the availability of data, but excluded all stations in the eastern Delta (Fig. 1) where salinity can be elevated by agricultural return flow. Data from 1975 to 2009 were averaged by month; data for the LSZ were missing for 13 out of 420 months. Primary production was estimated from chlorophyll concentration, extinction coefficient, and incident PAR from these data using a model developed by Cole and Cloern (1984). The free parameter $\Psi$ in this model is variable among years but on average changed from $\sim 0.7$ to $\sim 0.4$ sometime between 1989 and 2003 (Parker et al. 2012). Values of $\Psi$ used to extrapolate from the long-term monitoring data were set as follows: The earlier value was used for 1975-1988, the later value was used
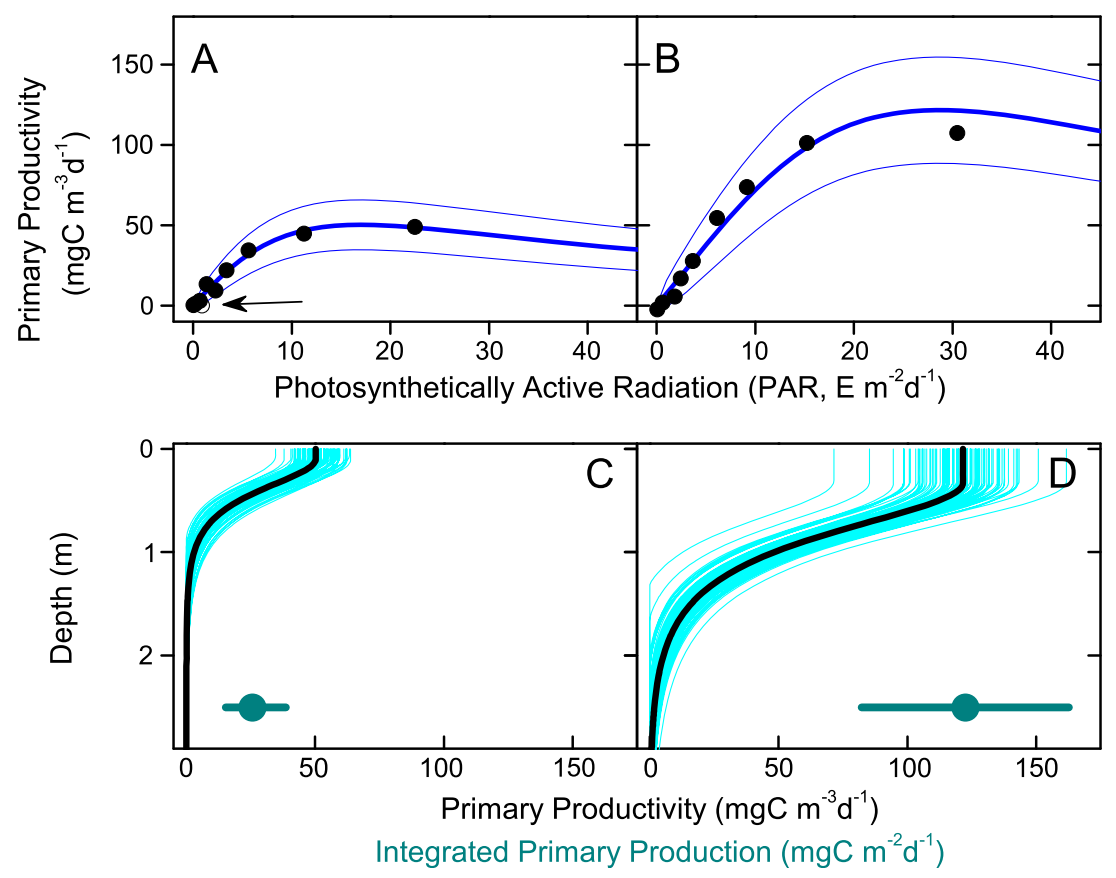

Fig. 3 Examples of data from two (of 217) productivity samples selected at random from within the top $(A, C)$ and bottom $(B, D)$ quartiles of integrated primary production. $A, B$ productivity vs. PAR curves showing raw data (points) and fitted curves (heavy lines) with 95\% confidence limits for the predictions (thin lines); arrow indicates a single point omitted from the fitting procedure in $A$ (see "Methods").
$C, D$ vertical profiles of productivity for the same samples as in $A$ and $B$. Thick lines calculated profiles; thin lines simulated profiles based on resampling from distributions for extinction, PAR, and PAR-productivity curves (i.e., confidence limits in $A$ and $B$ ). Error bars in $C$ and $D$ give calculated integrated primary production with $95 \%$ confidence limits 
from 2004 on, and the data from 1989 to 2003 were calculated alternatively with both values. Extinction coefficient was calculated from Secchi depth using Eq. 2 above. PAR was determined as described above except that for years before PAR data were available (1975-1982), we used the maximum theoretical PAR for each date (upper lines in Fig. 7) multiplied by the mean monthly ratio of observed PAR to the maximum PAR for all years when data were available.

\section{Results}

Phytoplankton biomass was concentrated mainly in five taxonomic groups with relatively little variation by salinity, season, or year in total biomass or in biomass of picoplankton or flagellates (Fig. 4). Biomass of centric diatoms, mainly Skeletonema costatum, was high only in spring 2006 and increased slightly with salinity. Biomass of pennate diatoms was high only in spring 2007 and to a lesser extent summer of 2007, with the benthic diatom Entomoneis sp. making up over half of the pennate biomass (Lidström 2009).

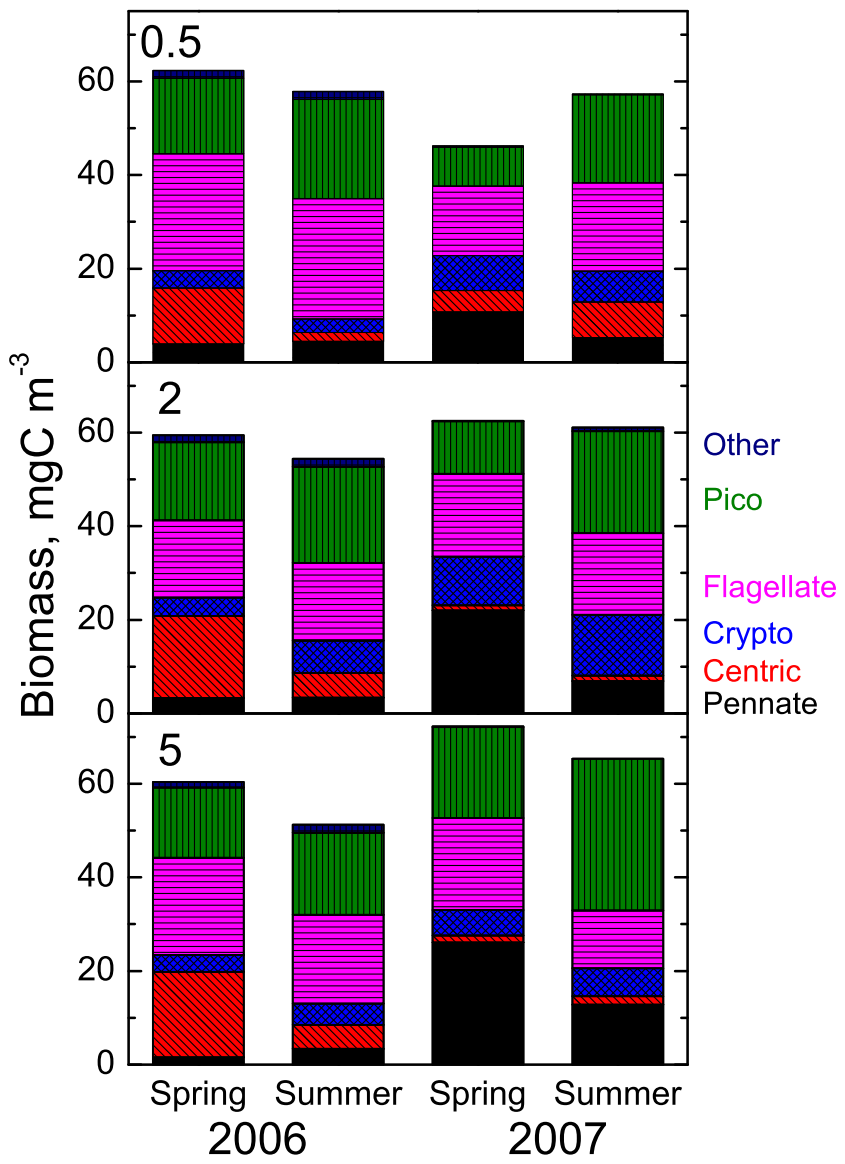

Fig. 4 Distribution of total phytoplankton biomass by major taxonomic group and sampling site (nominal salinity) for each year and season (spring $=$ March-May, summer=June-August). Data have been averaged among dates within seasons. Taxa are (from bottom) pennate diatoms, centric diatoms, cryptophytes, flagellates, picoplankton, and others
The time course of phytoplankton carbon for each year showed little pattern between spring and summer, and the annual means were $57 \pm 7 \mathrm{mg} \mathrm{Cm}^{-3}$ for both years (Fig. 5A, $\mathrm{B}$; here and elsewhere results are means with $95 \%$ confidence intervals unless otherwise stated). In contrast, chlorophyll was about twice as high and more variable in 2006 than in 2007, at $4.7 \pm 0.8$ and $2.4 \pm 0.4$, respectively, and higher in spring than in summer especially in 2006 (Fig. 5C, D). The 2006 means excluded data for all stations on 9 and 16 May and 13 June, when chlorophyll values for some samples were $<0.5 \mu \mathrm{g} \mathrm{l}{ }^{-1}$ for total chlorophyll or $<0.1 \mu \mathrm{gl}^{-1}$ for the $>5$ - $\mu \mathrm{m}$ size fraction. These low values were contradicted by phytoplankton carbon (Fig. 5A, B) and primary production (see below) and were well outside the range usually expected for summer in the SFE. These values likely arose through an undetected procedural error and have not been used in any statistical analyses. Chlorophyll $a$ values $>8 \mu \mathrm{g} 1^{-1}$ occurred four times in 2006 and only once in 2007. Carbon-tochlorophyll ratios were low, particularly in 2006 (Fig. 6), compared with predictions based on light-limited growth in culture (Cloern et al. 1995).

Extinction coefficients were less variable in 2006 than in 2007 , but means from the 2 years were similar $(3.6 \pm 0.4$ and $4.0 \pm 0.9 \mathrm{~m}^{-1}$, respectively, Fig. 5E, F). Photic zone depths (to $1 \%$ of surface PAR) calculated from mean extinction coefficients were 1.28 and $1.15 \mathrm{~m}$ for 2006 and 2007, respectively. Differences in extinction coefficient among salinities persisted only over parts of seasons, e.g., during 2006 the extinction coefficient was highest at station 0.5 during most of spring and often lowest at station 5 (Fig. 5E), but these patterns were roughly reversed in 2007 .

Incident PAR values calculated for the field sites were usually higher than those for the incubation site (Fig. 7). Coefficients of variation for PAR values at the incubation site averaged $\sim 3 \%$ when PAR was measured on site, and $10 \%$ for the incubation site when PAR was calculated using data from the two remote pyranometer stations.

Primary productivity was generally low with a few spikes, and similar among stations, during both years (Fig. 8). Annual means were $99 \pm 30$ and $114 \pm 25 \mathrm{mg} \mathrm{Cm}^{-2}$ day $^{-1}$ for 2006 and 2007, respectively. Confidence limits around individual sample values generally increased with the means. Most of the sampling error arose from either the curve fitted to the incubation data (median $77 \%$ of the variance) or the estimation of extinction coefficients (median 21\%), the latter mostly due to samples in which PAR profiles were missing and extinction was determined from Secchi depth. Relatively little of the variance in productivity was due to the PAR estimates (median $0.3 \%$ ). Productivity was unassociated with the proportions of biomass of the major phytoplankton groups (Fig. 4) except that high production in 2006 was associated with a high proportion of cryptophytes $(r=0.48 \pm 0.16$, bootstrap $95 \%$ confidence interval). 
Fig. 5 Phytoplankton biomass and extinction coefficient for 2006 (left column) and 2007 (right column). $A, B$ phytoplankton biomass based on estimated biovolume; $C, D$ chlorophyll $a ; E, F$ extinction coefficient. Error bars are 95\% confidence limits. Symbols give values from each station (by salinity, see key). Thick line means by survey; thin lines $(A-D)$ means by survey for samples filtered at $5 \mu \mathrm{m}$. Phytoplankton biomass $(A, B)$ is scaled to chlorophyll by the mean carbon-to-chlorophyll ratio

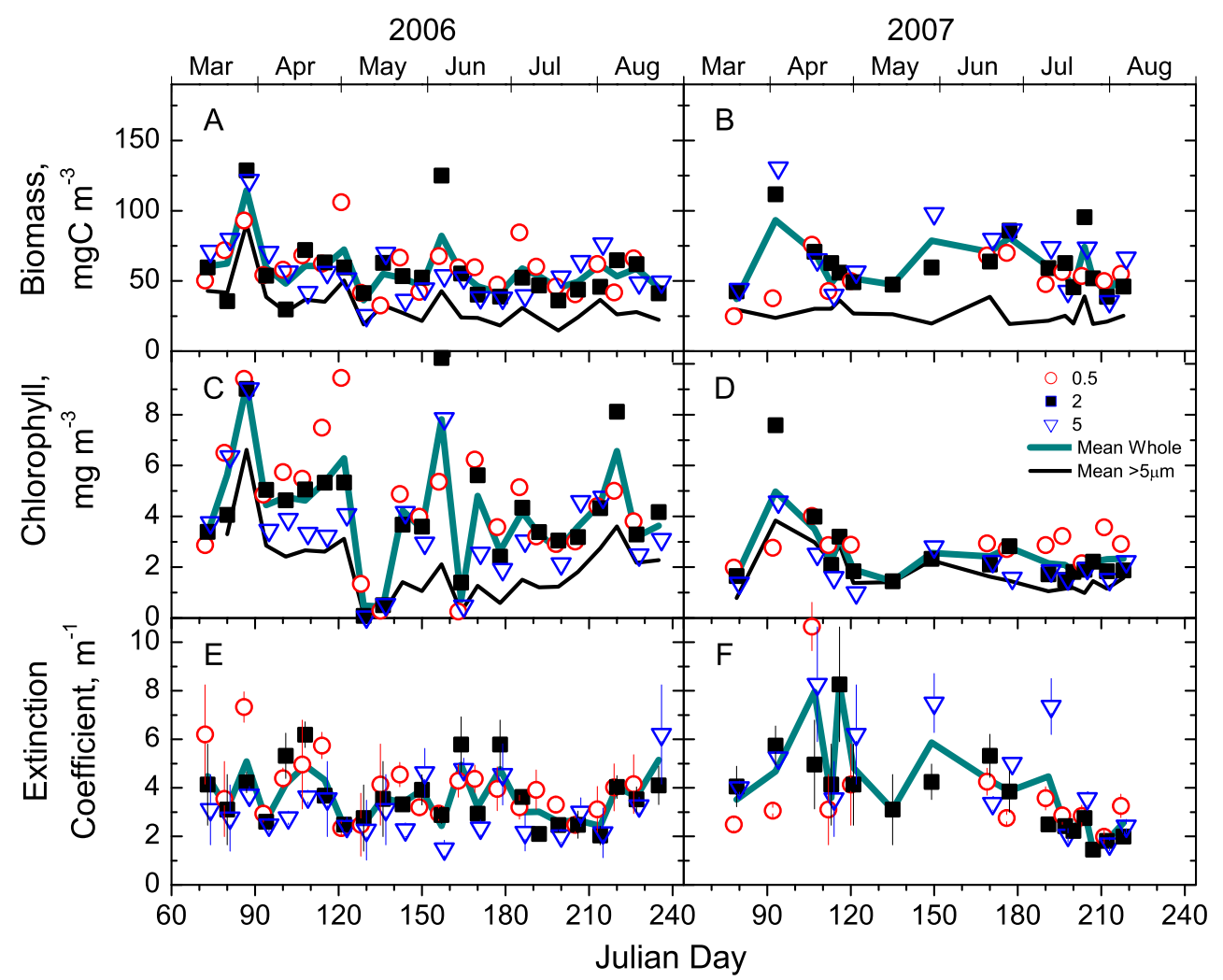

The $>5$ - $\mu \mathrm{m}$-size fractions of chlorophyll, phytoplankton carbon, and primary productivity were about half of the corresponding whole-water (GF/F) values during the 2 years (Table 1; Figs. 5 and 8 ). The $>5-\mu \mathrm{m}$ fraction of chlorophyll was $80-90 \%$ of the whole-water value in summer of 2007 , opposite the pattern in summer 2006 when only $\sim 30 \%$ of the chlorophyll was $>5 \mu \mathrm{m}$. This pattern was not reflected in the data for either phytoplankton carbon or production.

Nutrient concentrations (Table 2) during spring and summer of both years were generally high. The principal difference between the 2 years was the higher concentrations of nitrate, phosphate, and (in spring) ammonium in 2007 than in 2006. Ammonium concentration was negatively related to primary productivity when both were averaged across salinities to minimize redundancy. However, this relationship was much weaker than relationships of the log of productivity to light availability determined as the ratio of PAR to extinction coefficient (Table 3). Multiple regressions of log productivity against ammonium and light availability did not improve the fit, and the coefficient for ammonium was never significantly different from zero $(p>0.27)$.

Data from the long-term monitoring program (Fig. 9) show that the decline in chlorophyll concentration and primary production in 1987, likely attributable to grazing by C. amurensis, has persisted. Most of the decline in primary production was due to the decrease in phytoplankton biomass estimated as chlorophyll (Parker et al. 2012). The use of one or the other value of the model parameter $\Psi$ during the period between
1988 and 2004 (2 years when the parameter was estimated from primary production measurements, see Parker et al. 2012) alters the values by about 1.7 -fold but does not change the overall picture of persistently low primary production after 1987. Chlorophyll concentrations from our study averaged $\sim 60 \%$ higher in 2006 (without the three outliers) and $\sim 40 \%$ higher in 2007 than the long-term data for the same periods, and measured productivity was substantially higher than that calculated from long-term data (Fig. 9).

Annual primary production based on our data was calculated by assuming that the proportion of annual production occurring during March-August was the same in our data and the long-term data. The annual values were 25 and $31 \mathrm{gC} \mathrm{m}^{-2}$ year $^{-1}$.

\section{Discussion}

Banse (2002) questioned the value of continuing the measurement of primary production by the ${ }^{14} \mathrm{C}$ method for another 50 years and suggested that such measurements would be most useful if taken in an ecological framework. We have attempted to provide such a framework by developing insights into the importance of small-scale temporal and spatial variation including measurement error, variation in the carbon/ chlorophyll ratio, variation in the size and taxonomic composition of phytoplankton, and, in a companion paper, changes in the physiology of the phytoplankton (Parker et al. 2012; 


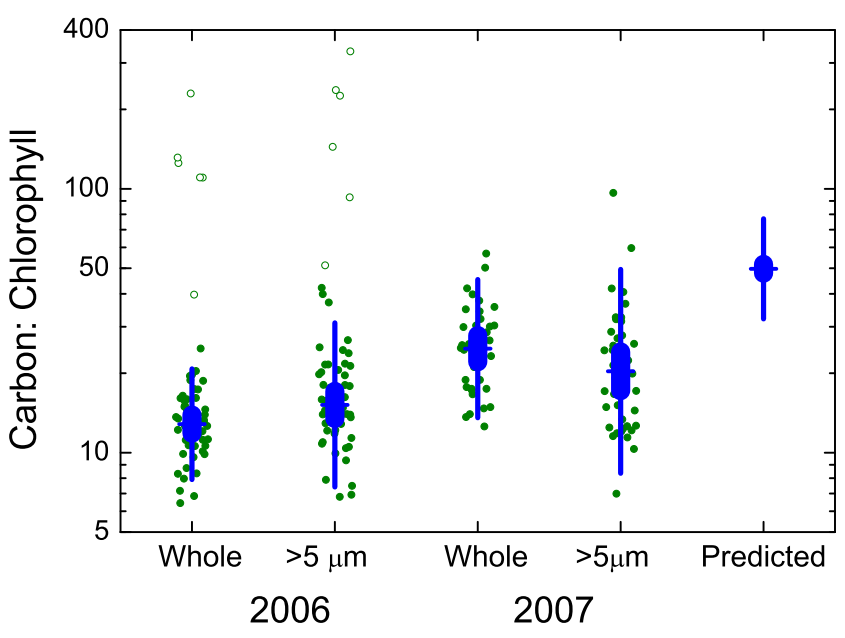

Fig. 6 Carbon/chlorophyll for 2006 and 2007, whole water (GF/F filter, $>0.7 \mu \mathrm{m})$ and $>5 \mu \mathrm{m}$ size fraction. Error bars give $95 \%$ confidence limits for the mean (bars) and for the raw data (lines). Open circles are data points excluded from most analyses because of anomalously low chlorophyll concentration (see text). Predicted values are based on Eq. 15 in Cloern et al. (1995) for conditions observed in 2006 and 2007, assuming no nutrient limitation

Fig. 9). This study is an essential component of a larger program examining many aspects of the food web in the LSZ (e.g., York et al. 2010; Gould and Kimmerer 2010) and the first examination of the influence of freshwater flow on primary productivity in this key region of the estuary.

Variability Despite the long history of primary production measurements, it is surprising to note the infrequent reporting of confidence intervals or even details of the methods used to derive depth-integrated production from incubation data (e.g., Jassby et al. 2002; Harding et al. 2002). This information seems important for distinguishing measurement error from important sources of environmental variability. We did not conduct replicate incubations, instead focusing our effort during each cruise on sampling across the LSZ to capture kilometer-scale spatial variability and using resampling (Fig. 3C, D) to develop confidence limits around estimates of integrated production.

Error in integrated production can arise from the method used for depth integration and, in simulated in situ incubations, from error in estimates of PAR and extinction coefficient. Relatively little of the variance in integrated primary productivity arose from error in PAR estimates. A modest fraction arose from estimates of extinction coefficient, but much of this error was due to the use of Secchi depth to fill in values from missing PAR profiles. Chlorophyll contributed about $1-3 \%$ (10th and 90th percentiles) to light extinction, using a published coefficient $\left(0.014 \mathrm{~m}^{-2}(\mathrm{mg} \mathrm{Chl})^{-1}\right.$, Atlas and Bannister 1980); the remainder of the light extinction was presumably due to inorganic particles.

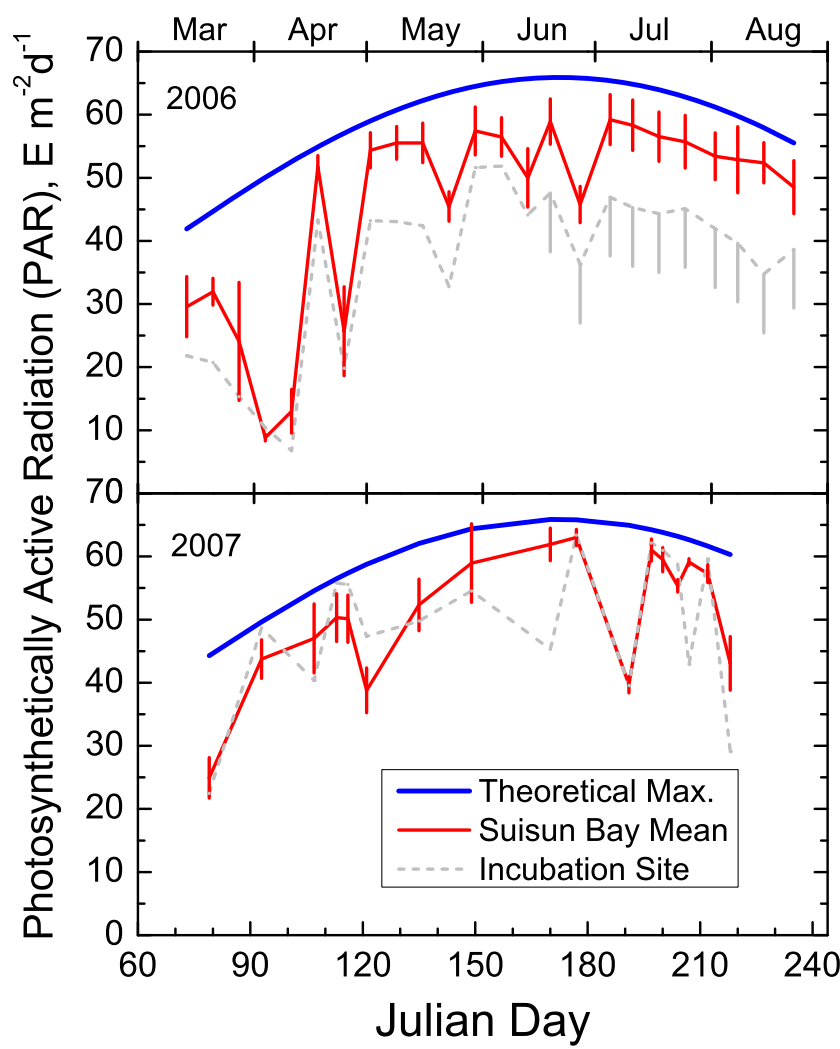

Fig. 7 PAR estimates for the incubation site and the collection site. Heavy line theoretical maximum PAR for the latitude. Solid line PAR estimates for Suisun Bay based on four stations; error bars are $95 \%$ confidence limits of the mean. Dashed line PAR at the incubation site at the Romberg Tiburon Center, either measured (no error bars) or calculated from two pyranometer stations (with upper confidence limits omitted for clarity as errors were symmetrical)

Most of the error in integrated production arose from the fit of Eq. 3 to the incubation data (Fig. 3A, B). Examination of the data and simple simulations showed that most of the variance in the profiles was due to a lack of fit at the highlight end of the profiles. Paradoxically, the high end of the productivity curve is most often neglected or cut off because of photoinhibition (e.g., Cole and Cloern 1984), yet this is the region where most of the production and therefore the variance lies. For investigating photophysiology of phytoplankton, an emphasis on low light is appropriate, but for determining integrated productivity, we recommend that future studies put most of their sampling effort into the high-light end of the profiles.

Allowing for error estimates, the measurements of primary production (Fig. 8) show some short-term temporal and small-scale spatial pattern. For example, the brief peaks in productivity at various times in 2006 occurred only at stations 2 and 5, not at 0.5. However, on most sampling dates, the confidence limits for the three stations overlapped, and no station had consistently higher production than the others, indicating that these stations could be treated as 
Fig. 8 Primary production by station (salinity) for 2006 (left column) and 2007 (right column). Error bars are 95\% confidence limits for whole water (GF/F filter; filled symbols); open symbols, $>5 \mu \mathrm{m}$ samples. Thick line, means by survey for whole-water samples

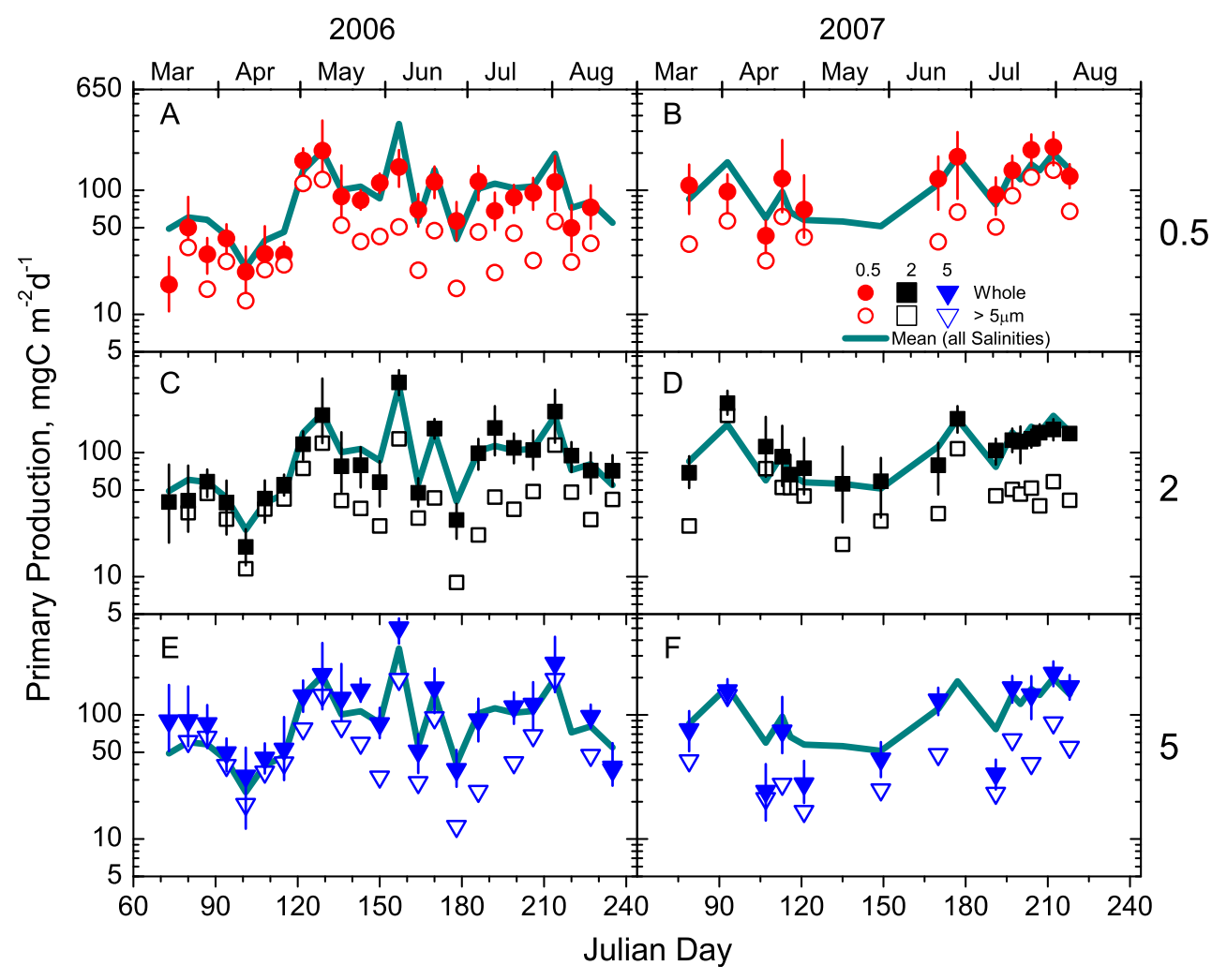

replicates for analysis of productivity in the LSZ. Furthermore, there was no evidence of variability at weekly time scales and in particular no correlation with spring-neap tidal cycles. This result gives us confidence in using monthly biomass data to extend our results beyond the limited time frame of our study.

Phytoplankton Composition and Productivity The carbonto-chlorophyll ratios determined in this study were at the low end of the reported range for marine and estuarine phytoplankton. For example, a synthesis of data from published experiments on cultured phytoplankton suggested ratios of $\sim 50$ were consistent with field conditions in this study (Cloern et al. 1995; Fig. 6). Light-limited cultures, more representative of conditions in the study area, have lower carbon/chlorophyll than cultures limited by nutrient concentrations (Laws and Bannister 1980). The methodological differences between these studies of cultured phytoplankton and our study, based on simultaneous field sampling for chlorophyll and carbon from microscopic counts, could account for this difference. Furthermore, it would be difficult to rule out bias in the estimates of phytoplankton carbon, particularly any bias due to failure to count a substantial part of the biomass.

Despite these concerns, we believe the carbon data are accurate. The $\Psi$ parameter used in the estimation of primary production from chlorophyll and available light appears to have decreased, consistent with a temporal decrease in carbon-to-chlorophyll ratios (Parker et al. 2012). Furthermore, using carbon in place of chlorophyll in that relationship led to a better fit and a more consistent result between years (Parker et al. 2012).

About $10 \%$ of the phytoplankton carbon in 2007 was in the benthic pennate diatom Entomoneis sp. (Lidström 2009). Entomoneis paludosa made up only about $0.1 \%$ of the biomass and occurred in about $20 \%$ of samples taken throughout San Francisco Bay during 1992-2001 (Cloern and Dufford 2005). This genus was not mentioned in other reports of phytoplankton species composition (Cloern et al. 1985; Lehman 1996, 2007). A recent diatom bloom (chlorophyll $>30 \mu \mathrm{g} \mathrm{l}^{-1}$ ) within the LSZ in spring 2010 was dominated first by Entomoneis sp. and later by Melosira sp. (R.C. Dugdale, SFSU, pers. comm. to W. Kimmerer, September 2011). Although the contribution of Entomoneis sp. to planktonic production is unknown, its sudden appearance as a substantial fraction of phytoplankton biomass may indicate yet another change of state in this fastchanging system (Thomson et al. 2010).

The size distribution of phytoplankton apparently shifted to smaller cells sometime after 1980 (Table 1), probably when $C$. amurensis became abundant in 1987 (Alpine and Cloern 1992). The $>5-\mu \mathrm{m}$-size fraction of phytoplankton carbon and primary production were both consistently around $50 \%$ of the GF/F fraction, and the only deviation from that pattern was a somewhat higher contribution of large cells in spring 2006 (Figs. 5 and 8). The $>5-\mu \mathrm{m}$ fraction of chlorophyll was less consistent, possibly reflecting differences in taxonomic 
Table 1 Percentages of total chlorophyll and, in this study only, phytoplankton carbon and primary production in various size fractions by region of the estuary and year

\begin{tabular}{|c|c|c|c|c|c|}
\hline Time period and references & Statistic & Location & $>5 \mu \mathrm{m}(\%)$ & $>10 \mu \mathrm{m}(\%)$ & $>22 \mu \mathrm{m}(\%)$ \\
\hline \multirow{3}{*}{$\begin{array}{l}1980 \text { (Cloern et al. 1985; } \\
\text { Cole et al. 1986) }\end{array}$} & \multirow[t]{3}{*}{ Chlorophyll annual mean } & Suisun & 96 & & 54 \\
\hline & & San Pablo & 80 & & 35 \\
\hline & & South & 78 & & 26 \\
\hline \multirow{3}{*}{$\begin{array}{l}\text { Spring } 1994 \text { (Kimmerer } \\
\text { et al. 1998, unpublished) }\end{array}$} & \multirow[t]{3}{*}{ Chlorophyll grand median from 3 cruises } & Suisun: $S=0.5$ & & 41 & \\
\hline & & Suisun: $S=1.6$ & & 25 & \\
\hline & & Suisun: $S=3.3$ & & 22 & \\
\hline \multirow{3}{*}{$\begin{array}{l}\text { Spring 2000-2003 } \\
\text { (Wilkerson et al. 2006) }\end{array}$} & \multirow[t]{3}{*}{ Chlorophyll seasonal means } & Suisun & 63 & & \\
\hline & & San Pablo & 80 & & \\
\hline & & Central & 72 & & \\
\hline \multirow{3}{*}{$\begin{array}{l}\text { Summer 2000-2003 } \\
\text { (Wilkerson et al. 2006) }\end{array}$} & \multirow[t]{3}{*}{ Chlorophyll seasonal means } & Suisun & 72 & & \\
\hline & & San Pablo & 57 & & \\
\hline & & Central & 26 & & \\
\hline 2006 (this study) & \multirow[t]{2}{*}{ Chlorophyll mean $\pm 95 \%$ CI } & San Pablo-Suisun & $48 \pm 5$ & & \\
\hline 2007 (this study) & & Suisun & $66 \pm 7$ & & \\
\hline 2006 (this study) & \multirow[t]{2}{*}{ Phytoplankton biomass mean $\pm 95 \% \mathrm{CI}$} & San Pablo-Suisun & $53 \pm 4$ & & \\
\hline 2007 (this study) & & Suisun & $50 \pm 4$ & & \\
\hline 2006 (this study) & \multirow[t]{2}{*}{ Integrated production: mean $\pm 95 \% \mathrm{CI}$} & San Pablo-Suisun & $54 \pm 4$ & & \\
\hline 2007 (this study) & & Suisun & $50 \pm 5$ & & \\
\hline
\end{tabular}

Data from 1994 are presented for three salinity values during three 30-h cruises in Suisun Bay to the western Delta

composition between years and seasons (Fig. 4). Typically in estuaries, the larger size fractions of both biomass and production are more variable than the smaller, such that blooms are typically characterized by a high proportion of larger cells (e.g., Iriarte and Purdie 1994; Smith and Kemp 2001; Revilla et al. 2002; Froneman 2004). The highest production periods in 2006 (Fig. 8) were not a result of high growth of large cells and did not rise to the level where they could be called blooms.

Temporal Patterns Cloern and Jassby $(2008,2010)$ described contrasting seasonal patterns of chlorophyll concentration among estuaries around the world. Even within the SFE, several contrasting patterns occur: Chlorophyll in the Delta is typically high in summer, as it was in the lowsalinity zone before 1987 (Jassby et al. 2002); by contrast, chlorophyll in south San Francisco Bay is the highest during approximately month-long spring blooms and shorter fall blooms (Cloern et al. 2007). The long-term data for the LSZ after 1987 had a weak seasonal pattern with chlorophyll highest in spring, especially in 2000 (Fig. 9).

Our data for 2006-2007 likewise show weak springsummer patterns for both phytoplankton biomass and primary production. The high temporal resolution of our sampling gave confidence that we did not miss any blooms. This is a concern with monthly sampling, which can miss the occasional spring blooms that have occurred in the LSZ in recent years (Fig. 9 and Dugdale et al. 2007). The short sampling interval and spatial replication were essential for our ongoing analysis of the LSZ food web; however, for routine monitoring a 2-3-week interval would be preferable to monthly sampling.

Nutrient concentrations were generally high and variation in nutrient concentrations probably did not influence productivity
Table 2 Mean surface nutrient concentrations $( \pm \mathrm{SD})$ for the LSZ as seasonal means for spring (March-May) and summer (June-August) during 2006 and 2007 in the LSZ

Data provided by F. Wilkerson (SFSU, personal communication)

\begin{tabular}{|c|c|c|c|c|c|}
\hline \multirow[t]{2}{*}{ Year } & \multirow[t]{2}{*}{ Season } & \multicolumn{2}{|l|}{ DIN } & \multirow[b]{2}{*}{$\mathrm{PO}_{4}\left(\mu \mathrm{mol} \mathrm{l}{ }^{-1}\right)$} & \multirow[b]{2}{*}{$\mathrm{Si}(\mathrm{OH})_{4}\left(\mu \mathrm{mol} \mathrm{l}^{-1}\right)$} \\
\hline & & $\begin{array}{l}\mathrm{NO}_{3}+\mathrm{NO}_{2} \\
\left(\mu \mathrm{mol} 1^{-1}\right)\end{array}$ & $\mathrm{NH}_{4}\left(\mu \mathrm{mol} \mathrm{l}{ }^{-1}\right)$ & & \\
\hline \multirow[t]{2}{*}{2006} & Spring $(n=36)$ & $14.66( \pm 3.31)$ & $4.27( \pm 0.73)$ & $1.85( \pm 0.27)$ & $219.9( \pm 45.8)$ \\
\hline & Summer $(n=33)$ & $17.86( \pm 2.70)$ & $4.30( \pm 1.32)$ & $1.25( \pm 0.44)$ & $224.1( \pm 34.0)$ \\
\hline \multirow[t]{2}{*}{2007} & Spring $(n=18)$ & $33.81( \pm 3.52)$ & $6.24( \pm 1.61)$ & $2.34( \pm 0.26)$ & $243.2( \pm 20.6)$ \\
\hline & Summer $(n=18)$ & $32.00( \pm 9.16)$ & $3.43( \pm 0.12)$ & $2.63( \pm 0.52)$ & $228.8( \pm 23.1)$ \\
\hline
\end{tabular}


Table 3 Regression results for the logs of three productivity variables against ammonium concentration and light availability as the ratio of PAR to extinction coefficient, a measure of the water-column mean light level (Cole and Cloern 1984)

\begin{tabular}{|c|c|c|c|c|}
\hline \multirow[t]{2}{*}{ Dependent variable } & \multirow[t]{2}{*}{ Year } & \multirow{2}{*}{$\begin{array}{l}\text { Number of } \\
\text { samples }\end{array}$} & \multicolumn{2}{|l|}{ Coefficients } \\
\hline & & & $\mathrm{NH}_{4}$ & Light \\
\hline \multirow[t]{2}{*}{ Log (productivity) } & 2006 & 22 & $-0.1 \pm 0.2$ & $0.07 \pm 0.02$ \\
\hline & 2007 & 13 & $-0.04 \pm 0.2$ & $0.04 \pm 0.02$ \\
\hline \multirow[t]{2}{*}{ Log (productivity/Chl) } & 2006 & 22 & $-0.1 \pm 0.3$ & $0.09 \pm 0.02$ \\
\hline & 2007 & 13 & $0.05 \pm 0.2$ & $0.06 \pm 0.04$ \\
\hline \multirow{2}{*}{$\begin{array}{l}\text { Log (productivity/ } \\
\text { phytoplankton C) }\end{array}$} & 2006 & 19 & $-0.12 \pm 0.3$ & $0.08 \pm 0.03$ \\
\hline & 2007 & 13 & $-0.01 \pm 0.1$ & $0.05 \pm 0.03$ \\
\hline
\end{tabular}

Results for whole-water samples only. Akaike information criterion for all six regressions was reduced when ammonium omitted, indicating that ammonium contributed nothing to the relationships

(Tables 2 and 3). The correlation between ammonium concentration and productivity was negative, but most of the variation in growth rate (productivity/biomass as chlorophyll or as phytoplankton carbon from counts) was explained by variation in light availability (Table 3 ). Phytoplankton growth may be inversely related to ammonium concentration through a combination of inhibition of nitrate uptake by ammonium concentration $>4 \mu \mathrm{M}$ and higher growth rate on nitrate than on ammonium (Wilkerson et al. 2006; Dugdale et al. 2007). In both years of our study, ammonium concentrations were persistently above this critical level; consequently, no effect of lower ammonium concentrations could be detected.

Freshwater Flow Flow has a strong influence on estuarine variability: It can influence nutrient loading (Nixon 2003), stratification (Cloern 1984), light penetration (Livingston et al. 1997), residence time (Jassby et al. 2002), and other factors (Drinkwater and Frank 1994; Kimmerer 2002) that influence chlorophyll and primary production (e.g., Mallin et al. 1993; Murrell et al. 2007). In many estuaries, freshwater flow is a key factor in stimulating primary production, most often through the correlation between flow and nutrient loading. In the SFE, abundances of many fish and macroinvertebrate species respond positively to freshwater flow (Jassby et al. 1995; Kimmerer 2002; Kimmerer et al. 2009), and this has led to management actions to protect these populations. In particular, freshwater flow is manipulated during late summer-autumn to protect the endangered delta smelt, an LSZ resident during this period.

The effects of freshwater flow on primary production in other estuaries suggest that the strong responses of some populations at higher trophic levels in the SFE may arise through a direct effect on primary productivity that propagates up through the food web. However, previous analyses have shown weak effects at lower trophic levels, leading to examination of alternative mechanisms for the observed positive responses (Kimmerer 2002; Kimmerer et al. 2009). These

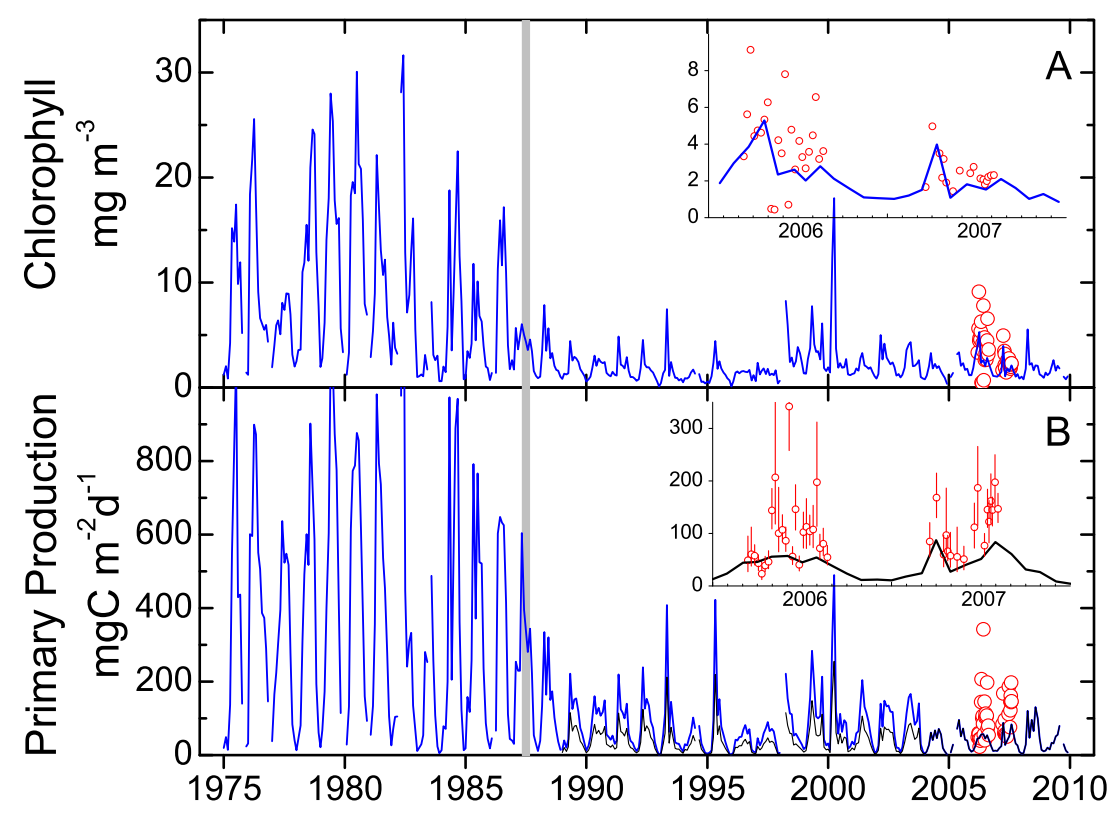

Fig. 9 Chlorophyll concentration $(A)$ and estimated primary production $(B)$ in this study and from a long-term monitoring program. Insets show data for 2006-2007 only. A Lines monthly means of chlorophyll from the Interagency Ecological Program environmental monitoring (Sommer et al. 2007) for stations in the western Delta to San Pablo Bay with salinity between 0.5 and 10 ; open circles means by date from all salinities in this study; $B$ Lines primary production estimated from IEP data on chlorophyll and Secchi depth and using PAR estimated as in Fig. 7; line from 1975 to 1988 and upper line to 2004 use the mean value of $\Psi$ determined from data of Cole and Cloern (1984), and the lower line and that after 2004 use the mean value of $\Psi$ from our data for 2006 and 2007 combined (Parker et al. 2012). Error bars in inset give $95 \%$ confidence limits 
analyses have relied on biomass measurements only, so our study is the first to examine the response of primary productivity across a wide range of freshwater flow.

Among the measures of biomass and production in the two size classes, only chlorophyll concentration in whole water was substantially higher in 2006 than 2007, despite a massive difference in freshwater input (Fig. 2) that resulted in major differences in position of the salinity field (Fig. 1). Higher chlorophyll in spring 2006 than in spring 2007 may have been due to the concentration of large phytoplankton cells by stronger estuarine circulation in the more compressed salinity gradient under high-flow conditions (Monismith et al. 2002). This was the only time when biomass of large centric diatoms was substantial (Fig. 4). Much of this biomass was in $S$. costatum, possibly entrained from deeper ocean-derived water into the surface (see Cloern and Cheng 1981).

Neither phytoplankton carbon biomass nor primary production was higher during the high-flow spring than the low-flow summer of 2006, nor in 2006 than in 2007 (Figs. 5 and 8). Growth rate of phytoplankton was closely related to light availability (Table 3), which was limited by low incident light during the storms that persisted into late spring of 2006 (Fig. 7).

This lack of response of productivity to freshwater flow contrasts sharply with results from systems in which nutrient loading or stratification results in a positive relationship of flow to primary production (e.g., Mallin et al. 1993) and highlights the need for estuarine researchers to consider carefully the geographic, hydrodynamic, and other attributes of these systems that influence how freshwater flow influences estuarine food webs. Variation in these attributes among estuaries may help to explain why estuaries differ so widely in their seasonal and annual patterns of variability (Cloern and Jassby 2008, 2010).

Even within the SFE, different regions differ from the LSZ in annual production, seasonal patterns (Cloern and Jassby 2008, 2010), and responses to freshwater flow. For example, chlorophyll and productivity in the freshwater Delta are inversely related to freshwater flow through its effect on residence time (Jassby et al. 2002; Jassby 2008). In south San Francisco Bay, spring blooms are the strongest when they follow wet winters because of the influence of stratification on bloom formation (Cloern 1984). Thus, the effect of freshwater flow on phytoplankton production varies in sign, magnitude, and mechanism among these three regions of the estuary.

The relationships of phytoplankton variables to flow might have looked very different had we sampled at fixed stations, because of movement of a persistent chlorophyll gradient with the salt field. Chlorophyll concentration is usually higher in the freshwater regions of the estuary than in the LSZ, so sampling at fixed stations would result in an apparent increase in chlorophyll with flow due only to advection. For example,
Cloern et al. (1983) described a positive relationship between chlorophyll in Suisun Bay (Fig. 1) and freshwater flow that was later ascribed to landward penetration of marine bivalves during a drought, resulting in high grazing and low biomass (Nichols 1985). Kimmerer (2002) showed that chlorophyll had been largely unresponsive to flow if the data were binned by salinity in a quasi-Lagrangian analysis. This was the finding that led us to sample at stations defined by salinity, following the previous approaches of Alpine and Cloern (1992) and Kimmerer et al. (1998).

The weak response of primary production to large variation in freshwater flow implies a weak response of the LSZ food web to the flow response of climate change. Historical data and model projections indicate a trend toward an earlier snowmelt peak resulting in higher flow in winter and lower flow in spring-summer. This implies higher productivity in the Delta because of longer residence time in spring-summer (Jassby et al. 2002) and possibly lower productivity in South San Francisco Bay through the influence of flow on stratification (Cloern 1984). However, the direct influence of reduced spring-summer flow on primary production within the LSZ is apparently small, particularly compared with the magnitudes of other influences such as species introductions (Alpine and Cloern 1992) and increasing water clarity (Kimmerer 2004; Nobriga et al. 2008).

Responses to freshwater flow over longer time scales, such as through changes in sediment supply (Schoellhamer 2011), may have a greater influence on the LSZ food web than immediate effects of flow. However, other changes over a time scale of decades, such as additional species introductions, net removal of sediment from the estuary, or massive changes in the configuration of subsided lands and water diversion facilities (Lund et al. 2007), may be even more influential than climate for this region of the estuary.

Food Web Implications Our study lasted only two seasons within 2 years, although at an intensive sampling rate. We placed these results in a longer-term context by using monitoring data (Fig. 9). Chlorophyll values were generally higher in our data, apart from the 3 days of anomalously low chlorophyll in 2006, but temporal patterns were similar. Since mid-1987, except for occasional brief blooms, chlorophyll has not risen above $\sim 10 \mu \mathrm{g} \mathrm{Chl} \mathrm{l}^{-1}$ which is roughly the threshold below which feeding by crustacean zooplankton becomes food-limited (e.g., Mueller-Solger et al. 2002). Wilkerson et al. (2006) also reported that chlorophyll in Suisun Bay was continuously low except for brief blooms in spring 2000 and 2003. The sharp decline in chlorophyll during summer 1987 coincided with the spread of the introduced clam C. amurensis (Nichols et al. 1990), which has maintained a filtration rate high enough to suppress most phytoplankton blooms in the northern estuary (Alpine and Cloern 1992; Thompson 2005; Kimmerer 2006). 
Productivity data (Fig. 9) also show a long-term reduction, although our measured values were high compared with estimates based on the long-term data. That difference arose from the higher chlorophyll values as well as somewhat lower extinction coefficients in our study than in the long-term program, probably because that program takes some samples in shallow waters of higher turbidity, whereas we sampled only in channels. In addition, sampling in the long-term monitoring program is planned to occur within an hour of the slack after flood, when turbidity may be higher than at other times, whereas we sampled without regard to tidal stage. The selection of a high (based on data from 1980) or low (Parker et al. 2012) parameter $\Psi$ to calculate productivity makes a substantial difference in the calculated values (Fig. 9). The lower value of $\Psi$ suggests an even greater long-term decline in productivity than suggested by the chlorophyll data.

Lacking a long time series of size-fractionated chlorophyll, we can infer changes in size distribution of phytoplankton only from a few short-term studies. These data (Table 1) show evidence of a long-term decline in the proportion of chlorophyll in large-size fractions. The longterm shift in phytoplankton from diatoms to flagellates and cyanobacteria has been discussed by Lehman (1996) and Glibert (2010), although the mechanism behind this shift remains in dispute. The timings of declines in apparent silica uptake in Suisun Bay (1987; Kimmerer 2005) and in abundance of anchovies in the LSZ (summer 1987; Kimmerer 2006) are consistent with an influence of size-selective grazing by the clam $C$. amurensis. This has been demonstrated by the lower feeding rate of clams on bacteria (typically $<1 \mu \mathrm{m}$ ) than on phytoplankton (Werner and Hollibaugh 1993). Thus, the phytoplankton biomass actually available to many grazers (typically $>5$ or $10 \mu \mathrm{m}$; Berggreen et al. 1988) is considerably lower than indicated by bulk chlorophyll values.

With this long-term perspective, it seems likely that the persistently low productivity at the base of the food web, particularly for larger cells, has affected higher trophic levels. Long-term declines, some directly linked to the 1987 decline in phytoplankton biomass, have been noted in several fish and zooplankton species (Kimmerer et al. 1994, 2009; Orsi and Mecum 1996; Kimmerer and Orsi 1996; Feyrer et al. 2003; Kimmerer 2006). The more recent (2002) decline in pelagic organisms (Sommer et al. 2007), by contrast, was not associated with a further decline in chlorophyll (Jassby 2008; Thomson et al. 2010) or, by inference, primary production. Nevertheless, the combination of low productivity and a high proportion of small cells offers poor support to the food web of the upper estuary, likely resulting in shifts in diet and food limitation and contributing to the poor condition of some fish species (Feyrer et al. 2003; Bennett 2005) and the general pattern of decline across species and trophic levels.
Although primary production values determined in this study are low compared with values from other well-studied estuaries, they are not anomalous. For example, primary production in turbid regions of the Elbe, Westerschelde, and Gironde estuaries were of similar magnitude or even lower than values reported here (Goosen et al. 1999).

Nixon's (1988) well-known relationship of fishery production to primary production indicates that, at the calculated rates of annual primary production in this study, fishery yield for the SFE low-salinity zone would be a meager $2 \mathrm{~kg} \mathrm{ha}^{-1}$ year $^{-1}$. Productivity is somewhat higher elsewhere in the system, both in the Sacramento-San Joaquin Delta (Jassby et al. 2002) and in south San Francisco Bay (Cloern et al. 2007). Nevertheless, the lack of a substantial commercial fishery in the San Francisco Estuary probably reflects the overall low productivity in this system.

Acknowledgments We thank J. Tirindelli for assistance with primary productivity measurements; A. Gould, T. Ignoffo, A. Slaughter, and J. York for assistance in the field and the laboratory; A. Marchi for running the nutrient analyses; and D. Bell and D. Morgan for vessel and logistic support. R. Dugdale, F. Wilkerson, and M. Weaver provided helpful comments. Funding was provided by the CALFED Bay-Delta Science Program under grant SCI-05-C107.

Open Access This article is distributed under the terms of the Creative Commons Attribution License which permits any use, distribution, and reproduction in any medium, provided the original author(s) and the source are credited.

\section{References}

Alpine, A.E., and J.E. Cloern. 1992. Trophic interactions and direct physical effects control phytoplankton biomass and production in an estuary. Limnology and Oceanography 37: 946-955.

Arar, E. J., and G. B. Collins. 1992. In vitro determination of chlorophyll $a$ and phaeophytin a in marine and freshwater phytoplankton by fluorescence-USEPA Method 445.0. USEPA methods for determination of chemical substances in marine and estuarine environmental samples. Cincinnati, Ohio.

Atlas, D., and T.T. Bannister. 1980. Dependence of mean spectral extinction coefficient of phytoplankton on depth, water color, and species. Limnology and Oceanography 25: 157-159.

Banse, K. 2002. Should we continue to measure ${ }^{14} \mathrm{C}$ uptake by phytoplankton for another 50 years? Limnology and Oceanography Bulletin 11: 45-46.

Baxter, R., R. Breuer, L. Brown, M. Chotkowski, F. Feyrer, M. Gingras, B. Herbold, A. Mueller-Solger, M. Nobriga, T. Sommer, and K. Souza. 2008. Pelagic organism decline progress report: 2007 synthesis of results. Sacramento. http://www.fws.gov/sacramento/es/ documents/POD_report_2007.pdf. Accessed 21 June 2011.

Bennett, W. A. 2005. Critical assessment of the delta smelt population in the San Francisco Estuary, California. San Francisco Estuary and Watershed Science 3: Issue 2 Article 1.

Berggreen, U., B. Hansen, and T. Kiørboe. 1988. Food size spectra, ingestion and growth of the copepod Acartia tonsa during development: implications for determination of copepod production. Marine Biology 99: 341-352. 
Bran + Leubbe. 1999. AutoAnalyzer method no. G-177-96 silicate in water and seawater. Buffalo Grove: Bran Luebbe.

Brown, L.R., W. Kimmerer, and R. Brown. 2008. Managing water to protect fish: a review of California's Environmental Water Account. Environmental Management 43: 357-368.

Cloern, J.E. 1984. Temporal dynamics and ecological significance of salinity stratification in an estuary (South San Francisco Bay, USA). Oceanologica Acta 7: 137-141.

Cloern, J.E. 1991. Annual variations in river flow and primary production in the South San Francisco Bay estuary (USA). In Estuaries and coasts: spatial and temporal intercomparisons, ed. M. Elliott and J.-P. Ducrotoy, 91-96. Fredensborg: Olsen and Olsen.

Cloern, J.E., and R.T. Cheng. 1981. Simulation model of Skeletonema costatum population dynamics in northern San Francisco Bay, California. Estuarine, Coastal and Shelf Science 12: 83-100.

Cloern, J.E., and R. Dufford. 2005. Phytoplankton community ecology: principles applied in San Francisco Bay. Marine Ecology Progress Series 285: 11-28.

Cloern, J.E., and A.D. Jassby. 2008. Complex seasonal patterns of primary producers at the land-sea interface. Ecology Letters 11: 1294-1303.

Cloern, J., and A. Jassby. 2010. Patterns and scales of phytoplankton variability in estuarine-coastal ecosystems. Estuaries and Coasts 33: 230-241.

Cloern, J., A. Alpine, B. Cole, R. Wong, J. Arthur, and M. Ball. 1983. River discharge controls phytoplankton dynamics in the northern San Francisco Bay estuary. Estuarine, Coastal and Shelf Science 16: 415-429.

Cloern, J.E., B.E. Cole, R.L.J. Wong, and A.E. Alpine. 1985. Temporal dynamics of estuarine phytoplankton: a case study of San Francisco Bay. Hydrobiologia 129: 153-176.

Cloern, J.E., C. Grenz, and L. Vidergar-Lucas. 1995. An empirical model of the phytoplankton chlorophyll/carbon ratio - the conversion factor between productivity and growth rate. Limnology and Oceanography 40: 1313-1321.

Cloern, J.E., A.D. Jassby, J.K. Thompson, and K.A. Hieb. 2007. A cold phase of the East Pacific triggers new phytoplankton blooms in San Francisco Bay. Proceedings of the National Academy of Sciences, USA 104: 18561-18565.

Cole, B.E., and J.E. Cloern. 1984. Significance of biomass and light availability to phytoplankton productivity in San Francisco Bay. Marine Ecology Progress Series 17: 15-24.

Cole, B.E., J.E. Cloern, and A.E. Alpine. 1986. Biomass and productivity of three phytoplankton size classes in San Francisco Bay. Estuaries 9: 117-126.

Dame, R., T. Chrzanowski, K. Bildstein, B. Kjerfve, H. McKellar, D. Nelson, J. Spurrier, S. Stancyk, H. Stevenson, J. Vernberg, and R. Zingmark. 1986. The outwelling hypothesis and North Inlet, South Carolina. Marine Ecology Progress Series 33: 217-229.

Drinkwater, K.F., and K.T. Frank. 1994. Effects of river regulation and diversion on marine fish and invertebrates. Aquatic Conservation: Marine and Freshwater Ecosystems 4: 135-151.

Dugdale, R.C., F.P. Wilkerson, V.E. Hogue, and A. Marchi. 2007. The role of ammonium and nitrate in spring bloom development in San Francisco Bay. Estuarine, Coastal and Shelf Science 73: 17-29.

Feyrer, F., B. Herbold, S.A. Matern, and P.B. Moyle. 2003. Dietary shifts in a stressed fish assemblage: Consequences of a bivalve invasion in the San Francisco Estuary. Environmental Biology of Fishes 67: 277-288.

Fischer, H.B., J.E. List, R. Koh, J. Imberger, and N.H. Brooks. 1979. Mixing in inland and coastal waters. San Diego: Academic.

Friederich, G.E., P.M. Walz, M.G. Burczynski, and F.P. Chavez. 2002. Inorganic carbon in the central California upwelling system during the 1997-1999 El Nino-La Nina event. Progress in Oceanography 54: 185-203.
Froneman, P.W. 2004. Food web dynamics in a temperate temporarily open/closed estuary (South Africa). Estuarine, Coastal and Shelf Science 59: 87-95.

Glibert, P.M. 2010. Long-term changes in nutrient loading and stoichiometry and their relationships with changes in the food web and dominant pelagic fish species in the San Francisco Estuary, California. Reviews in Fisheries Science 18: 211-232.

Goosen, N.K., J. Kromkamp, J. Peene, P. Van Rijswik, and P. Van Breugel. 1999. Bacterial and phytoplankton production in the maximum turbidity zone of three European estuaries: The Elbe, Westerschelde and Gironde. Journal of Marine Systems 22: 151171.

Gould, A.L., and W.J. Kimmerer. 2010. Development, growth, and reproduction of the cyclopoid copepod Limnoithona tetraspina in the upper San Francisco Estuary. Marine Ecology Progress Series 412: $163-177$.

Greene, V.E., L.J. Sullivan, J.K. Thompson, and W.J. Kimmerer. 2011. Grazing impact of the invasive clam Corbula amurensis on the microplankton assemblage of the northern San Francisco Estuary. Marine Ecology Progress Series 431: 183-193.

Guillard, R.R.L. 1978. Counting slides. In Phytoplankton manual, ed. A. Sournia, 182-189. Paris: UNESCO.

Harding, L.W., M.E. Mallonee, and E.S. Perry. 2002. Toward a predictive understanding of primary productivity in a temperate, partially stratified estuary. Estuarine, Coastal and Shelf Science 55: $437-463$.

Hillebrand, H., C.-D. Dürselen, D. Kirschtel, U. Pollingher, and T. Zohary. 1999. Biovolume calculation for pelagic and benthic microalgae. Journal of Phycology 35: 403-424.

Holm-Hansen, O., C.J. Lorenzen, R.W. Holmes, and J.D.H. Strickland. 1965. Fluorometric determination of chlorophyll. J. Cons. Perm. Int. Explor. Mer. 30(1): 3-15.

Iriarte, A., and D.A. Purdie. 1994. Size distribution of chlorophyll-a biomass and primary production in a temperate estuary (Southampton Water): The contribution of photosynthetic picoplankton. Marine Ecology Progress Series 115: 283-297.

Jassby, A. D. 2008. Phytoplankton in the upper San Francisco Estuary: Recent biomass trends, their causes and their trophic significance. San Francisco Estuary and Watershed Science 6: Issue 1 Article 2.

Jassby, A.D., and T. Platt. 1976. Mathematical formulation of the relationship between photosynthesis and light for phytoplankton. Limnology and Oceanography 21: 540-547.

Jassby, A.D., W.J. Kimmerer, S.G. Monismith, C. Armor, J.E. Cloern, T.M. Powell, J.R. Schubel, and T.J. Vendlinski. 1995. Isohaline position as a habitat indicator for estuarine populations. Ecological Applications 5: 272-289.

Jassby, A.D., J.E. Cloern, and B.E. Cole. 2002. Annual primary production: Patterns and mechanisms of change in a nutrient-rich tidal estuary. Limnology and Oceanography 47: 698-712.

JGOFS. 1996. JGOFS report no. 19-protocols for the Joint Global Ocean Flux Studies (JGOFS) core measurements. In International JGOFS report series, 128-134 (ISSN 1016-7331).

Kimmerer, W.J. 2002. Effects of freshwater flow on abundance of estuarine organisms: physical effects or trophic linkages? Marine Ecology Progress Series 243: 39-55.

Kimmerer, W. J. 2004. Open water processes of the San Francisco Estuary: From physical forcing to biological responses. San Francisco Estuary and Watershed Science (Online Serial) 2: Issue 1, Article 1.

Kimmerer, W.J. 2005. Long-term changes in apparent uptake of silica in the San Francisco estuary. Limnology and Oceanography 50: 793-798.

Kimmerer, W.J. 2006. Response of anchovies dampens effects of the invasive bivalve Corbula amurensis on the San Francisco Estuary foodweb. Marine Ecology Progress Series 324: 207-218. 
Kimmerer, W.J., and J.J. Orsi. 1996. Causes of long-term declines in zooplankton in the San Francisco Bay estuary since 1987. In San Francisco Bay: The ecosystem, ed. J.T. Hollibaugh, 403-424. San Francisco: AAAS.

Kimmerer, W.J., E. Gartside, and J.J. Orsi. 1994. Predation by an introduced clam as the probable cause of substantial declines in zooplankton in San Francisco Bay. Marine Ecology Progress Series 113: 81-93.

Kimmerer, W.J., J.R. Burau, and W.A. Bennett. 1998. Tidally-oriented vertical migration and position maintenance of zooplankton in a temperate estuary. Limnology and Oceanography 43: 1697-1709.

Kimmerer, W.J., E.S. Gross, and M. MacWilliams. 2009. Variation of physical habitat for estuarine nekton with freshwater flow in the San Francisco Estuary. Estuaries and Coasts 32: 375-389.

Kneib, R.T. 1997. The role of tidal marshes in the ecology of estuarine nekton. Oceanography and Marine Biology Annual Review 35: 163-220.

Laws, E.A., and T.T. Bannister. 1980. Nutrient- and light-limited growth of Thalassiosira fluviatilis in continuous culture, with implications for phytoplankton growth in the ocean. Limnology and Oceanography 25: 457-473.

Lehman, P.W. 1996. Changes in chlorophyll a concentration and phytoplankton community composition with water-year type in the upper San Francisco Estuary. In San Francisco Bay: The ecosystem, ed. J.T. Hollibaugh, 351-374. San Francisco: AAAS.

Lehman, P.W. 2007. The influence of phytoplankton community composition on primary productivity along the riverine to freshwater tidal continuum in the San Joaquin River, California. Estuaries and Coasts 30: 82-93.

Lidström, U. E. 2009. Primary production, biomass and species composition of phytoplankton in the low salinity zone of the northern San Francisco Estuary. MS thesis, San Francisco State University.

Livingston, R.J., X.F. Niu, F.G. Lewis, and G.C. Woodsum. 1997. Freshwater input to a gulf estuary: Long-term control of trophic organization. Ecological Applications 7: 277-299.

Lund, J., E. Hanak, W. Fleenor, R. Howitt, J. Mount, and P. Moyle. 2007. Envisioning futures for the Sacramento-San Joaquin Delta. San Francisco: Public Policy Institute of California.

Macedo, M.F., and P. Duarte. 2006. Phytoplankton production modelling in three marine ecosystems - static versus dynamic approach. Ecological Modelling 190: 299-316.

MacIsaac, E.A., and J.G. Stockner. 1993. Enumeration of phototrophic picoplankton by autofluorescence microscopy. In Handbook of methods in aquatic microbial ecology, ed. P.F. Kemp, B.F. Sherr, E.B. Sherr, and J.J. Cole. Boca Raton: Lewis.

Mallin, M.A., H.W. Paerl, J. Rudek, and P.W. Bates. 1993. Regulation of estuarine primary production by watershed rainfall and river flow. Marine Ecology Progress Series 93: 199-203.

Malone, T.C. 1977. Light-saturated photosynthesis by phytoplankton size fractions in New York Bight, USA. Marine Biology 42: 281-292.

Mccullagh, P., and J. Nelder. 1989. Generalized linear models. London: Chapman and Hall.

Menden-Deuer, S., and E.J. Lessard. 2000. Carbon to volume relationships for dinoflagellates, diatoms, and other protist plankton. Limnology and Oceanography 45(3): 569-579.

Monismith, S.G., W.J. Kimmerer, J.R. Burau, and M.T. Stacey. 2002. Structure and flow-induced variability of the subtidal salinity field in northern San Francisco Bay. Journal of Physical Oceanography 32: 3003-3019.

Morel, A., and R.C. Smith. 1974. Relation between total quanta and total energy for aquatic photosynthesis. Limnology and Oceanography 19: 591-600.

Mueller-Solger, A.B., A.D. Jassby, and D. Müller-Navarra. 2002. Nutritional quality of food resources for zooplankton (Daphnia) in a tidal freshwater system (Sacramento-San Joaquin River Delta). Limnology and Oceanography 47: 1468-1476.

Murrell, M., J. Hagy, E. Lores, and R. Greene. 2007. Phytoplankton production and nutrient distributions in a subtropical estuary: Importance of freshwater flow. Estuaries and Coasts 30: 390 402.

Nichols, F.H. 1985. Increased benthic grazing: An alternative explanation for low phytoplankton biomass in northern San Francisco Bay during the 1976-1977 drought. Estuarine, Coastal and Shelf Science 21: 379-388.

Nichols, F.H., J.K. Thompson, and L.E. Schemel. 1990. Remarkable invasion of San Francisco Bay (California, USA) by the Asian clam Potamocorbula amurensis. 2. Displacement of a former community. Marine Ecology Progress Series 66: 95-101.

Nixon, S.W. 1988. Physical energy inputs and the comparative ecology of lake and marine ecosystems. Limnology and Oceanography 33: $1005-1025$.

Nixon, S.W. 2003. Replacing the Nile: Are anthropogenic nutrients providing the fertility once brought to the Mediterranean by a great river? Ambio 32: 30-39.

Nobriga, M., T. Sommer, F. Feyrer, and K. Fleming. 2008. Long-term trends in summertime habitat suitability for delta smelt, Hypomesus transpacificus. San Francisco Estuary and Watershed Science 6: Issue 1 Article 1.

Orsi, J.J., and W.L. Mecum. 1996. Food limitation as the probable cause of a long-term decline in the abundance of Neomysis mercedis the opossum shrimp in the Sacramento-San Joaquin estuary. In San Francisco Bay: The ecosystem, ed. J.T. Hollibaugh, 375401. San Francisco: AAAS.

Pahl-Wostl, C., and D.M. Imboden. 1990. DYPHORA - a dynamic model for the rate of photosynthesis of algae. Journal of Plankton Research 12: 1207-1221.

Parker, A.E., W.J. Kimmerer, and U. Lidstrőm. 2012. Re-evaluating the generality of an empirical model for light-limited primary production in the San Francisco Estuary. Estuaries and Coasts (in press).

Revilla, M., A. Ansotegui, A. Iriarte, I. Madariaga, E. Orive, A. Sarobe, and J.M. Trigueros. 2002. Microplankton metabolism along a trophic gradient in a shallow-temperate estuary. Estuaries 25: 6-18.

Schoellhamer, D. H. 2011. Sudden clearing of estuarine waters upon crossing the threshold from transport to supply regulation of sediment transport as an erodible sediment pool is depleted: San Francisco Bay, 1999. Estuaries and Coasts 34: 885-899.

Sharp, J., K. Yoshiyama, A. Parker, M. Schwartz, S. Curless, A. Beauregard, J. Ossolinski, and A. Davis. 2009. A biogeochemical view of estuarine eutrophication: Seasonal and spatial trends and correlations in the Delaware Estuary. Estuaries and Coasts 32: 1023-1043.

Smith, E.M., and W.M. Kemp. 2001. Size structure and the production/ respiration balance in a coastal plankton community. Limnology and Oceanography 46: 473-485.

Sobczak, W.V., J.E. Cloern, A.D. Jassby, B.E. Cole, T.S. Schraga, and A. Arnsberg. 2005. Detritus fuels ecosystem metabolism but not metazoan food webs in San Francisco estuary's freshwater delta. Estuaries 28: 124-137.

Solórzano, L. 1969. Determination of ammonia in natural waters by phenolhypochlorite method. Limnology and Oceanography 14: 799-801.

Sommer, T., C. Armor, R. Baxter, R. Breuer, L. Brown, M. Chotkowski, S. Culberson, F. Feyrer, M. Gingras, B. Herbold, W. Kimmerer, A. Mueller Solger, M. Nobriga, and K. Souza. 2007. The collapse of pelagic fishes in the upper San Francisco Estuary. Fisheries 32: 270 277. 
Steemann Nielsen, E. 1952. The use of radioactive carbon $\left(\mathrm{C}^{14}\right)$ for measuring organic carbon production in the sea. Journal Cons Perm International Exploration Mer 18: 117-140.

Thompson, J. K. 2005. One estuary, one invasion, two responses: Phytoplankton and benthic community dynamics determine the effect of an estuarine invasive suspension-feeder. In Comparative roles of suspension-feeders in ecosystems: NATO Science Series IV Earth and Environmental Sciences 47, 291-316.

Thomson, J., W. Kimmerer, L. Brown, K. Newman, R. Mac Nally, W. Bennett, F. Feyrer, and E. Fleishman. 2010. Bayesian changepoint analysis of abundance trends for pelagic fishes in the upper San Francisco Estuary. Ecological Applications 1431-1448: $1431-1448$.

Throndsen, J. 1978. Centrifugation. In Phytoplankton manual, ed. A. Sournia, 98-103. Paris: UNESCO.

Tomas, C.R. 1996. Identifying marine diatoms and dinoflagellates. San Diego: Academic.

Venables, W.N., and B.N. Ripley. 2003. Modern applied statistics with $S$, 4th ed. New York: Springer.
Verity, P.G., C.Y. Robertson, C.R. Tronzo, M.G. Andrews, J.R. Nelson, and M.E. Sieracki. 1992. Relationships between cell volume and the carbon and nitrogen content of marine photosynthetic nanoplankton. Limnology and Oceanography 37(7): 1434-1446.

Wehr, J.D., and R.G. Sheath. 2003. Freshwater algae of North America: Ecology and classification. San Diego: Academic.

Werner, I., and J.T. Hollibaugh. 1993. Potamocorbula amurensiscomparison of clearance rates and assimilation efficiencies for phytoplankton and bacterioplankton. Limnology and Oceanography 38: 949-964.

Whitledge, T.E., S. Malloy, C.J. Patton, \& C.D. Wirick, 1981. Automated nutrient analysis in seawater. Brookhaven National Laboratory Tech. Rep. BNL 51398. 226 pp.

Wilkerson, F.P., R.C. Dugdale, V.E. Hogue, and A. Marchi. 2006. Phytoplankton blooms and nitrogen productivity in San Francisco Bay. Estuaries and Coasts 29: 401-416.

York, J., B. Costas, and G. McManus. 2010. Microzooplankton grazing in green water-results from two contrasting estuaries. Estuaries and Coasts 34: 373-385. 